\title{
How to Turn an Electron Transfer Protein into a Redox Enzyme for Biosensing
}

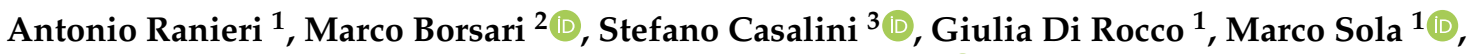 \\ Carlo Augusto Bortolotti ${ }^{1, *}$ and Gianantonio Battistuzzi ${ }^{2, *}$
}

1 Department of Life Sciences, University of Modena and Reggio Emilia, Via Campi 103, 41125 Modena, Italy; antonio.ranieri@unimore.it (A.R.); giulia.dirocco@unimore.it (G.D.R.); marco.sola@unimore.it (M.S.)

2 Department of Chemical and Geological Sciences, University of Modena and Reggio Emilia, Via Campi 103, 41125 Modena, Italy; marco.borsari@unimore.it

3 Department of Chemical Sciences, University of Padova, Via Marzolo 1, 35131 Padova, Italy; stefano.casalini@unipd.it

* Correspondence: carloaugusto.bortolotti@unimore.it (C.A.B.); gianantonio.battistuzzi@unimore.it (G.B.); Tel.: +39-059-205-8608 (C.A.B.); +39-059-20-8639 (G.B.)

check for updates

Citation: Ranieri, A.; Borsari, M.; Casalini, S.; Di Rocco, G.; Sola, M.; Bortolotti, C.A.; Battistuzzi, G. How to Turn an Electron Transfer Protein into a Redox Enzyme for Biosensing. Molecules 2021, 26, 4950. https:// doi.org/10.3390/molecules26164950

Academic Editor: Frantisek Hartl

Received: 26 July 2021

Accepted: 13 August 2021

Published: 16 August 2021

Publisher's Note: MDPI stays neutral with regard to jurisdictional claims in published maps and institutional affiliations.

Copyright: (c) 2021 by the authors. Licensee MDPI, Basel, Switzerland. This article is an open access article distributed under the terms and conditions of the Creative Commons Attribution (CC BY) license (https:// creativecommons.org/licenses/by/ $4.0 /)$.

\begin{abstract}
Cytochrome $c$ is a small globular protein whose main physiological role is to shuttle electrons within the mitochondrial electron transport chain. This protein has been widely investigated, especially as a paradigmatic system for understanding the fundamental aspects of biological electron transfer and protein folding. Nevertheless, cytochrome $c$ can also be endowed with a non-native catalytic activity and be immobilized on an electrode surface for the development of third generation biosensors. Here, an overview is offered of the most significant examples of such a functional transformation, carried out by either point mutation(s) or controlled unfolding. The latter can be induced chemically or upon protein immobilization on hydrophobic self-assembled monolayers. We critically discuss the potential held by these systems as core constituents of amperometric biosensors, along with the issues that need to be addressed to optimize their applicability and response.
\end{abstract}

Keywords: redox biosensing; cytochrome $c$; surface immobilization

\section{Introduction}

The heme group is the most abundant metal cofactor in living organisms and is involved in many different biological functions, from $\mathrm{O}_{2}$ binding and transport, to redox catalysis, from electron shuttling, to molecular sensing [1-4]. The reason for this large variety of functions is the chemical versatility of the heme center the reactivity of which is modulated and fine-tuned by the protein matrix, which may control the iron atom axial coordination and spin state, the accessibility to solvent and exogenous molecules, and the polarity of the surrounding environment [3-7].

The multiplicity of physiological roles and the ease of isolation, genetic manipulation, and physico-chemical characterization have made electrode-immobilized native and mutated heme proteins the species of choice for the development of bio(in)organic interfaces for (bio)sensing and catalysis [5,6,8-15]. Exploiting the direct adsorption or covalent attachment of the redox-active protein on the electrode surface proved to be an attractive and promising approach, leading to the development of efficient third-generation amperometric biosensors for substrates of clinical and industrial relevance $\left(\mathrm{O}_{2}, \mathrm{H}_{2} \mathrm{O}_{2}, \mathrm{NO}_{2}{ }^{-}\right)$[5,6,8-15]. Its main drawback consists in the immobilization-induced protein unfolding and inactivation, which may severely hamper the electrochemical and electrocatalytic responses $[5,6]$. This is particularly relevant for globins, peroxidases, catalases, and cytochrome P450, since their heme $b$ is not covalently bound to the protein matrix and can be partially or completely released upon protein denaturation, generating electrochemical responses due to non-native conformers or freely-diffusing heme groups in solution [5,16-18]. 
Two approaches are applied to overcome this problem. The first consists in the development of more efficient strategies of protein-electrode immobilization, which effectively couple preservation of the native protein structure with efficient electrical communication [5,6,19-24]. The most common immobilization techniques consist in protein physisorption or covalent attachment on (i) the bare electrode surfaces, (ii) electrodes surfacemodified with self-assembled monolayers (SAMs) of alkanethiols, or (iii) nanomaterials (Au nanoparticles, carbon nanotubes, graphene), and iv) protein encapsulation into different porous matrices (often incorporating redox mediators or carbon nanotubes) [5,6,19-31].

The second strategy, which is applied in combination with the former, is based on the possibility of effectively modulating and controlling the reactivity of heme proteins by rationally designed mutations in key positions [32-36]. Of particular interest is the replacement of five-coordinated heme $b$-containing proteins (which feature an open heme coordination site for substrate binding) with engineered single and multi-heme cytochromes $c$ as the core constituents of the hybrid sensing interfaces $[8,9,15,37-40]$. The rationale of this approach is that these species, whose reactivity can be made comparable to that of the replaced proteins, are more robust and more resistant to immobilization-induced unfolding and heme release, due to the presence of covalently bound hemes $c[8,9,15,37-43]$. The feasibility of this approach has been demonstrated by the ability of mutated cytochromes $c$ to catalyze the electrocatalytic reduction of $\mathrm{O}_{2}, \mathrm{H}_{2} \mathrm{O}_{2}$, and $\mathrm{NO}_{2}{ }^{-}[8,9,15,37-40,44]$.

Cytochromes $c$ constitute a large and ubiquitous family of redox metalloproteins containing one or more hemes $c$ covalently bound to the sidechains of two cysteine residues [45-47]. Mitochondrial cytochromes $c$ (cytc hereafter) are the most thoroughly characterized species. Cytc is a small globular protein (ca. $13 \mathrm{kDa}$ ) that contains a single six-coordinate heme $c$ embedded into a hydrophobic environment, and whose axial iron coordination positions are occupied by His18 and Met80 [45-48]. Under physiological conditions, cytc is located in the intermembrane space of mitochondria, where it participates in the electron transport chain, shuttling electrons from cytochrome $c$ reductase (complex III) to cytochrome $c$ oxidase (complex IV).

Due to its relative simplicity, stability, and availability, cytc has long been adopted as a robust model for understanding the molecular details of biological electron transfer and protein folding and stability [41-43,45-56]. These studies revealed the existence of several non-native conformations, whose 3D structure, heme environment, and axial ligation depend on the solution properties and binding events [41-43,45-49,55-86]. This structural flexibility is crucial for controlling the physiological role of the protein, as well as its reactivity in vitro $[41-43,48,49,51,57,62,63,65,68,75-80,83,84,87-100]$, since the observed changes in heme axial ligation, coordination number, and accessibility confer to cytochrome $c$ the ability to bind and catalyze the reduction of small exogenous molecules (such as $\mathrm{O}_{2}$, $\mathrm{H}_{2} \mathrm{O}_{2}$ and $\left.\mathrm{NO}_{2}{ }^{-}\right)$, turning it from an ET protein into an efficient redox enzyme $[8,9,15,37-$ $39,41,43,44,63,83-85,93,98,101-105]$.

Indeed, it is now well established that cytc is a multi-tasking protein, whose structural properties and biological role depend on external stimuli and cellular location $[48,56,57,68,75$, $93,106]$. Its role as an apoptotic trigger is the epitome of this tunable functionality in vivo. This function depends on cytc release into the cytosol, which is activated by binding to the negatively charged glycerophospholipid cardiolipin (CL) found in the inner mitochondrial membrane (IMM) $[48,93,106,107]$. The interaction with CL induces a conformational transition accompanied by the cleavage of the Fe-S(Met80) bond $[48,57,62,63,68,75,77,93,95,103,107-109]$, which imparts cytc with a significant (lipo)peroxidase activity toward CL itself, crucial for the permeabilization of the mitochondrial membrane $[48,57,63,68,75,93,107,108,110,111]$. Moreover, cytc can move into the nucleus in response to DNA damage, preventing nucleosome assembly and blocking cell survival $[48,75,112]$; although the mechanism of translocation and the conformations involved in each step are still unknown.

In vitro, chemical denaturation of freely diffusing and surface-immobilized cytc (due to extreme $\mathrm{pH}$ values, denaturing agents, organic solvents, or lipid membranes) induces a heme axial ligand swapping similar to that observed upon CL binding in vivo, resulting 
in non-native low spin His/Lys and His/His axially ligated forms and 5-coordinate highspin His-ligated species [38,39,44,102,103,113-115], featuring good pseudo-peroxidase and nitrite-reductase performances.

Here, we describe how to turn cytc into an efficient redox enzyme, for the development of bioinorganic interfaces for third generation amperometric biosensors for small substrates $\left(\mathrm{O}_{2}, \mathrm{H}_{2} \mathrm{O}_{2}, \mathrm{NO}_{2}{ }^{-}\right)$, through exploitation of (i) point mutations and (ii) chemicalor adsorption-induced unfolding, also in the presence of lipid membranes, coupled with immobilization on the surface of solid electrodes.

\section{Exploiting Point Mutations}

We can identify three major structural features that prevent cytochrome $c$ from functioning as an efficient electrocatalyst in its native, folded state (which, on the other hand, are the same that allow it to act as an ET species) [9,44]. The most relevant is the lack of a free position in the iron coordination sphere, in contrast with native heme enzymes, which feature either a five-coordinate iron or a weakly bound sixth axial ligand that is easily displaced by the substrate [1,2]. The second factor is the poor accessibility of the heme pocket to potential substrates. Third, the heme pocket lacks a base catalyst, as the distal His in heme peroxidases, which would facilitate the catalytic mechanism [116].

In the last two decades, the rational design of engineered cytc with non-native enzymatic activity has been devoted to lifting at least one of the aforementioned structural limitations [117-121]. Here, we will focus exclusively on electrode immobilized mutant cytochromes $c$ turned into the core components of potential electrochemical biosensors.

The most relevant example of an ad hoc designed site-directed mutant of cytochrome $c$ endowed with catalytic activity is the M80A mutant, in which the axial iron ligand methionine at position 80 (Figure 1) was replaced by a non-coordinating alanine residue. Despite the mutation, the iron is still hexacoordinated by an $\mathrm{OH}^{-}$ion that protonates with a $\mathrm{pK}_{\mathrm{a}}$ of $5.6[37,121-127]$ that, however, could easily be replaced by small molecules such as dioxygen, hydrogen peroxide, or anions (e.g., nitrite) $[8,9,37,122-124,126]$, as detailed below.

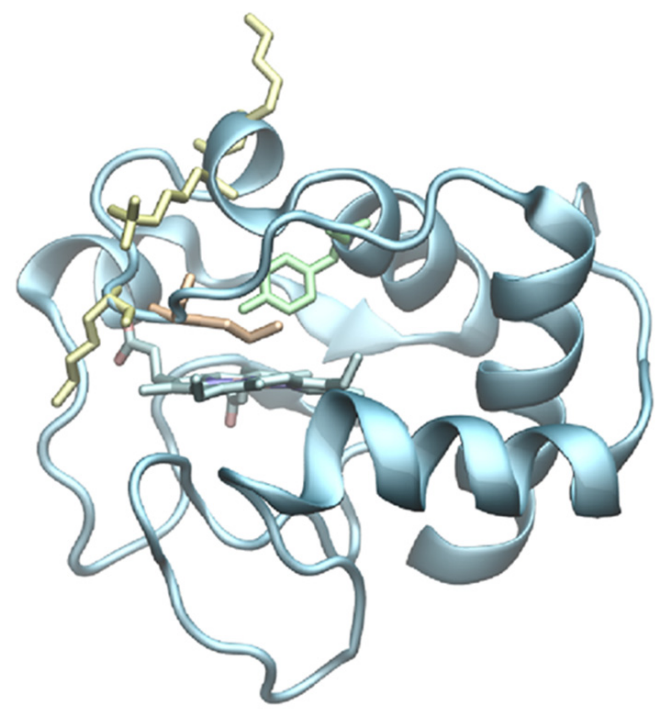

Figure 1. Cartoon representing the 3D structure of wild type yeast cytochrome $c$ (PDB 2YCC) highlighting Met80 (orange), Tyr67 (light green), and Lys 72, Lys73, and Lys 79 (yellow).

In 2008, our group described the electrocatalytic properties of the M80A mutant of yeast cytc immobilized on self-assembled monolayers (SAMs) formed either by a mixture of mercaptoundecanoic acid/mercaptoundecanol (MUA/MU hereafter) or by 4-mercaptopyridine (4-MP) [37]. On the former SAM, the M80A mutant mainly adsorbs via electrostatic interactions between the negatively-charged SAM headgroups and the 
surface-exposed lysines of the protein, as indicated by the loss of the redox signals at high ionic strength. Conversely, the M80A mutant is believed to bind to the 4-MP SAM mostly via hydrogen bonds involving pyridine nitrogen and interfacial water molecules. In both cases, the $E^{\circ \prime}$ value at $25^{\circ} \mathrm{C}$ for the immobilized protein is about $400 \mathrm{mV}$ more negative compared to the wt species under the same conditions, most likely as a consequence of the replacement of the soft S(Met) axial ligand with the hard hydroxide ion $[9,37]$.

For M80A cytc on MUA/MU, electrocatalytic waves were observed upon increasing the concentration of $\mathrm{O}_{2}$ in the solution (Figure 2), which could be attributed to the electrocatalytic dioxygen reduction carried out by the adsorbed mutant. Such a response was observed both at slightly acidic (5.1) and neutral $\mathrm{pH}$ values [37]. When bound to the 4-MP modified gold electrode, M80A cytc could electrocatalytically reduce $\mathrm{O}_{2}$ in a wider $\mathrm{pH}$ range (namely $\mathrm{pH} 5,7$, and 10) [37].
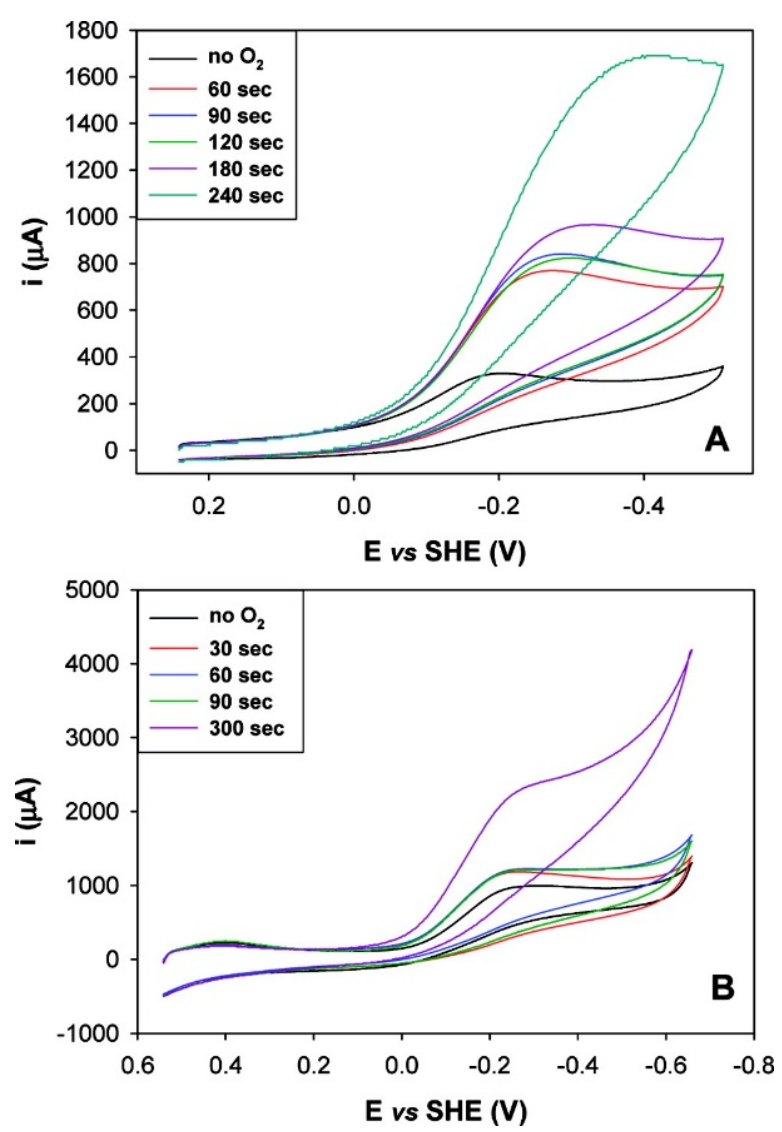

Figure 2. Cyclic voltammograms for the M80A/C102T mutant of yeast iso-1-cytochrome $c$ immobilized on a polycrystalline gold electrode coated with a SAM of 1:1 MUA/MU at pH 5.2 (A) and 7 (B), recorded upon increasing exposure to air. For solution composition and other experimental conditions, the reader is referred to the original literature. Reprinted with permission from ref. [37]. Copyright 2008 American Chemical Society.

These remarkable electrocatalytic properties are probably due to the large intrinsic affinity of $\mathrm{O}_{2}$ for the $\mathrm{Fe}(\mathrm{II})$ heme and to the weakening of the bond between the heme iron and the axial ligand $\left(\mathrm{OH}^{-}\right.$or $\mathrm{H}_{2} \mathrm{O}$, depending on the $\left.\mathrm{pH}\right)$ upon $\mathrm{Fe}(\mathrm{III})$ reduction, which facilitates the binding of $\mathrm{O}_{2}$ to the ferrous heme. The most severe limitation to the practical use of the above described construct was the loss of the protein response upon extensive electrochemical cycling, most likely due to oxidative disruption of the MUA/MU or 4-MP monolayers by the radical species yielded by dioxygen reduction (possibly superoxide anion) [37]. 
As stability over prolonged electrochemical cycling is an important prerequisite for amperometric biosensing, the M80A mutation was coupled to two further substitutions to introduce a single, surface exposed cysteine (Cys62) for direct covalent immobilization of the protein on bare Au working electrodes [8]. The M80A/N62C/C102T mutant covalently bound to bare gold was indeed able to electrocatalytically reduce $\mathrm{O}_{2}$ with higher catalytic currents over a wider $\mathrm{pH}$ range (from 3 to 10) compared to the physiosorbed M80A variant, and, most notably, its electrochemical response did not fade upon prolonged electrocatalytic activity [8].

The M80A/N62C/C102T mutant was also able to electrocatalytically reduce the nitrite anion upon immobilization on 4-MP, on MUA/MU, and when covalently bound to bare $\mathrm{Au}$ [8]. Independently of the surface confinement strategy, when the ion concentration was increased to the micromolar range, an increase of the cathodic current, accompanied by a decrease of the anodic one, was observed (Figure 3) [8].
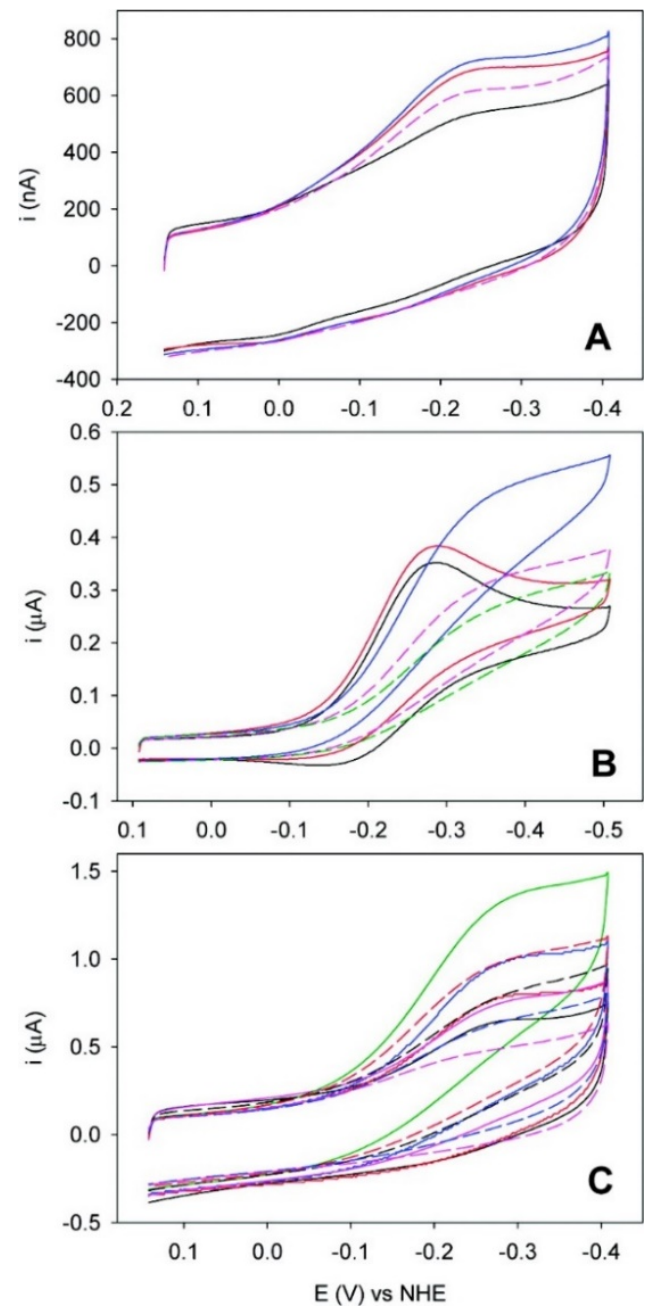

Figure 3. Cyclic voltammograms recorded in the presence of increasing concentrations of sodium nitrite for the M80A variant of yeast iso-1-cytochrome $c$ immobilized with different procedures on a polycrystalline gold electrode at $\mathrm{pH}$ 7. (A) M80A/C102T on a SAM 4-MP (black, no nitrite; red, $10 \mu \mathrm{M}$; blue, $20 \mu \mathrm{M}$; magenta, $100 \mu \mathrm{M}$ ), (B) M80A/C102T on a SAM of MUA/MU (black, no nitrite; red, $1 \mu \mathrm{M}$; blue, $5 \mu \mathrm{M}$; magenta, $15 \mu \mathrm{M}$; green, $20 \mu \mathrm{M}$ ), and (C) M80A/N62C/C102T covalently linked to the electrode through an Au-S(Cys) bond (black, no nitrite; red, $1 \mu \mathrm{M}$; magenta, $2 \mu \mathrm{M}$, blue, $5 \mu \mathrm{M}$; green, $10 \mu \mathrm{M}$; dashed red, $20 \mu \mathrm{M}$; dashed black, $30 \mu \mathrm{M}$; dashed magenta, $50 \mu \mathrm{M})$. For the solution composition and other experimental conditions, the reader is referred to the original literature. Reprinted with permission from ref. [8]. Copyright 2008 American Chemical Society. 
The proposed two-step mechanism first involves reduction of heme iron (which destabilizes the bond with the $\mathrm{OH}^{-}$anion serving as the sixth ligand) followed by the one-electron reduction of nitrite to $\mathrm{NO}[8,39,44]$ :

$$
\begin{gathered}
\text { cytc-Fe(III)-OH }{ }^{-}+\mathrm{e}^{-} \rightarrow \text { cytc-Fe(II) }+\mathrm{OH}^{-} \\
\text {cytc-Fe(II) }+\mathrm{NO}_{2}{ }^{-}+\mathrm{H}^{+} \rightarrow \text { cytc-Fe(III)-OH }{ }^{-}+\mathrm{NO}
\end{gathered}
$$

The catalytic activity of the electrode-immobilized M80A/N62C/C102T mutant was successfully estimated using the Michaelis-Menten model, expressing the MichaelisMenten equation in terms of current density $[8,39,44]$ :

$$
\frac{1}{j_{c}}=\frac{1}{j_{\max }}+\frac{K_{M}}{j_{\max } \cdot\left[N O_{2}^{-}\right]}
$$

where $j_{c}$ and $j_{\max }$ are the electrocatalytic current density and the maximum current density at substrate saturation, respectively (Figure 4).

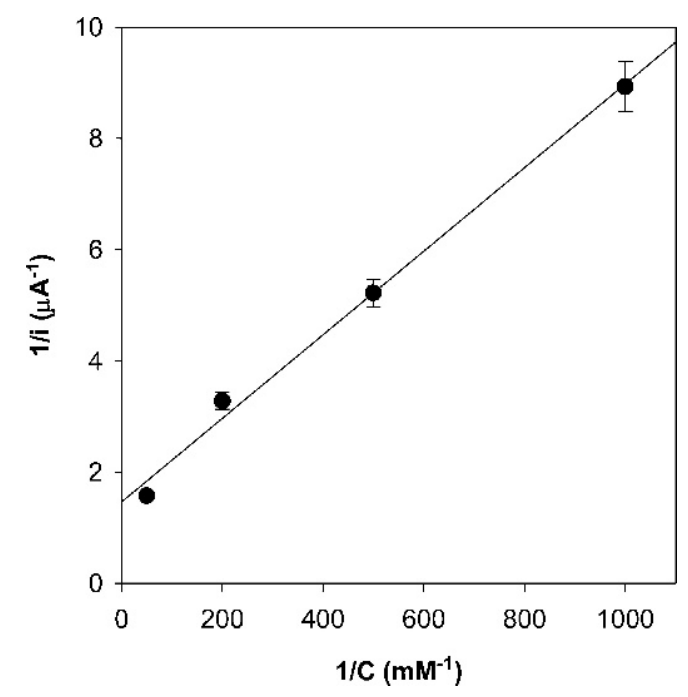

Figure 4. Lineweaver-Burk plot for the electrocatalytic currents yielded by the M80A/N62C/C102T variant of yeast iso-1-cytochrome $c$ covalently linked to the electrode through an Au-S(Cys) bond, $\mathrm{pH} 7$, in the presence of increasing nitrite ion concentrations. Reprinted with permission from ref. [8]. Copyright 2008 American Chemical Society.

The latter is the electrochemical equivalent of $v_{\max }$ in the usual Michaelis-Menten model and depends on $k_{\text {cat }}$ and on the surface concentration of the catalytically active protein on the electrode. Hence, fluctuations in $j_{\max }$ are directly connected to $k_{c a t}$ changes, provided that the protein coverage of the SAM is conserved. As a consequence, $j_{\max }$ reflects the ability of electrode-immobilized M80A/N62C/C102T mutant to catalyze the reduction of $\mathrm{NO}_{2}{ }^{-}[8,39,44] . K_{M}$ indicates the kinetic affinity between the protein and substrate, the smaller the $K_{M}$ values the higher the protein affinity for $\mathrm{NO}_{2}{ }^{-}$.

The cathodic current decreases for $\left[\mathrm{NO}_{2}^{-}\right]>20 \mu \mathrm{M}$, possibly as a consequence of electrostatic interactions between the anion and the positively charged lysine-rich patches on the protein surface, which might induce a conformational change detrimental to the catalytic activity [8]. The $K_{M}$ and $j_{\max }$ values are $5.1 \mu \mathrm{M}$ and $2.14 \mu \mathrm{A} \mathrm{cm}{ }^{-2}$ (Table 1), respectively [8]. $K_{M}$ values in the micromolar range indicate a significant kinetic affinity of the nitrite ion for the mutant (much larger than that for myoglobin or cytochrome P450, which show larger $K_{M}$ values, by about three orders of magnitude $\left.[128,129]\right)$. The $j_{\max }$ values are informative on the catalytic efficiency, which turns out to be comparable to that of a freely diffusing nitrite reductase accepting electrons via heterogeneous ET from surface-immobilized cytc ${ }_{551}$ [130]. 
Table 1. Kinetic parameters for the electrocatalytic reduction of $\mathrm{NO}_{2}{ }^{-}$carried out by wt yeast iso- 1 cytochrome $c$ (ycc) and some of its variants covalently bound to a bare polycrystalline gold electrode (M80A/N62C/C102T) or adsorbed on a polycrystalline gold electrode coated with a SAM of MUA/MU or 1-DT (M80A and M80A/Y67A). For the solution composition, experimental conditions, and uncertainties associated with the reported values, the reader is referred to the original literature.

\begin{tabular}{|c|c|c|c|c|}
\hline & $K_{M}(\mu \mathrm{M})$ & $\begin{array}{c}J_{\max } \\
\left(\mu \mathrm{A} \mathrm{cm}^{-2}\right)\end{array}$ & $\begin{array}{c}J_{\max } / K_{M} \\
\left(\mu \mathrm{A} \mathrm{cm}^{-2} \mu \mathrm{M}^{-1}\right)\end{array}$ & Ref. \\
\hline \multicolumn{5}{|c|}{ Protein covalently bound to a bare Au electrode } \\
\hline $\mathrm{M} 80 \mathrm{~A} / \mathrm{N} 62 \mathrm{C} / \mathrm{C} 102 \mathrm{~T}^{\mathrm{a}}$ & 5.1 & 2.14 & 0.42 & [8] \\
\hline \multicolumn{5}{|c|}{ Protein adsorbed on a Au electrode surface-modified with a MUA/MU SAM } \\
\hline wt ycc folded & - & - & - & [44] \\
\hline wt ycc unfolded (7 M urea) & - & - & - & [44] \\
\hline M80A ycc unfolded (7 M urea) & 0.64 & 3.47 & 5.42 & [44] \\
\hline M80A/Y67A ycc folded & 5.96 & 2.78 & 0.47 & [44] \\
\hline M80A/Y67A ycc unfolded (7 M urea) & 4.51 & 3.95 & 0.88 & [44] \\
\hline \multicolumn{5}{|c|}{ Protein adsorbed on a Au electrode surface-modified with a 1-DT SAM } \\
\hline wt ycc & - & - & - & [39] \\
\hline wt ycc + CL & - & - & - & [39] \\
\hline M80A yсc & 0.22 & $1.20^{b}$ & $5.46^{\mathrm{b}}$ & [39] \\
\hline $\mathrm{M} 80 \mathrm{~A}$ ycc $+\mathrm{CL}$ & 0.37 & $1.50^{b}$ & $4.04^{b}$ & [39] \\
\hline M80A/Y67А усс & 0.43 & $1.42^{b}$ & $3.30^{b}$ & [39] \\
\hline $\mathrm{M} 80 \mathrm{~A} / \mathrm{Y} 67 \mathrm{~A}$ ycc $+\mathrm{CL}$ & 0.85 & $1.35^{\mathrm{b}}$ & $1.59^{b}$ & [39] \\
\hline
\end{tabular}

a These kinetic parameters correspond to those for the electrocatalytic reduction of $\mathrm{NO}_{2}{ }^{-}$by the folded M80A variant, since covalent binding of the M80A/N62C/C102T variant to a bare polycrystalline gold electrode does not induce protein unfolding. ${ }^{b}$ Calculated by multiplying the data reported in Table 3 of ref. [39] by the corresponding electrode surface coverages $\Gamma_{0}$.

Very recently, our group investigated the electrocatalytic properties of a surface-bound M80A mutant in mixed organic/water solvent [82]. Retaining peroxidase-like activity in a non-fully aqueous environment is crucial for exploitation of the construct in real life applications. In particular, M80A was electrostatically physisorbed on a MUA/MU mixed SAM, and its electrocatalytic activity towards $\mathrm{H}_{2} \mathrm{O}_{2}$ reduction was measured in dimethylsulfoxide (DMSO)/water mixtures [82]. The mutant retained its peroxidase-like properties up to $60 \% v / v$ DMSO, while at higher DMSO concentrations a marked decrease of the activity occurred, most likely due to conformational changes, as indicated by changes in the reduction thermodynamics and ET kinetics [82].

Besides substitution of an axial ligand with a non-coordinating residue, the heme pocket was further modified to make it more similar to that of native heme redox enzymes. A key residue in this respect is the highly conserved Tyr67, which plays a crucial structural role, through its extended hydrogen bond network within the heme pocket $[127,131,132]$. To assess the role played by Tyr67, several research groups produced and characterized cytc variants at position 67, exploring changes at the structural level and in the peroxidase-like activity $[117,119,120]$. The two most widely explored mutations for yeast and human cytcs were Y67H and Y67R $[117,119,120]$. Interestingly, the Y67H mutation has little structural effects, despite the weakening of the Fe-S(Met80) bond [120]. On the contrary, in the Y67R mutant of human cytc, the Fe-S(Met80) bond is lost, resulting in an eight-fold increase of peroxidase activity with respect to the wt protein [120], possibly due to the stabilization of the negative charge of the Fe(III)-OOH complex by the newly introduced Arg67 during Compound I formation.

To assess whether addition of a mutation at Tyr67 to the Met80-to-Ala swapping further enhances the catalytic properties of cytc, our group investigated the electrochemical behavior of the double mutants M80A/Y67H and M80A/Y67A of yeast cytc adsorbed on an MUA/MU-modified gold electrode [9]. The near invariance of the $E^{\circ \prime}$ values suggested that the $\mathrm{Y} 67 / \mathrm{A}-\mathrm{H}$ changes did not induce relevant structural differences compared to the single M80A mutant. Both double variants were able to electrocatalytically reduce $\mathrm{H}_{2} \mathrm{O}_{2}$ in the low micromolar range [9]. An irreversible catalytic activity loss occured at 
$\mathrm{H}_{2} \mathrm{O}_{2}$ concentrations higher than $5 \mu \mathrm{M}$ and $18 \mu \mathrm{M}$, respectively, which could be ascribed to oxidative damage to the protein and/or loss of the heme iron [9].

The catalytic activity of the M80A variant and both double mutants was again estimated using the Michaelis-Menten equation, expressed in terms of current density [9]:

$$
\frac{1}{j_{c}}=\frac{1}{j_{\max }}+\frac{K_{M}}{j_{\max } \cdot\left[\mathrm{H}_{2} \mathrm{O}_{2}\right]}
$$

Perhaps surprisingly, the immobilized M80A/Y67H and M80A/Y67A displayed poorer peroxidase-like capability than M80A, as indicated by lower $j_{\max }$ values ( 3 and 10 times smaller than M80A for M80A/Y67H and M80A/Y67A, respectively) and slightly higher $K_{M}$ values (Table 2) [9]. Therefore, despite resulting in a larger heme cavity, the Tyr67 substitution removes a residue that is important for efficient catalytic turnover, most likely thanks to its involvement in the $\mathrm{H}$-bond to hydrogen peroxide or hydroperoxide anion.

Table 2. Kinetic parameters for the electrocatalytic reduction of $\mathrm{H}_{2} \mathrm{O}_{2}$ carried out by wt beef heart cytochrome $c$ (bcc), wt yeast iso-1 cytochrome $c$ (ycc) and its K79A, K73A, K72A/K73A, K72A/K73A/K79A, K72A/K73H/K79A, M80A, $\mathrm{M} 80 \mathrm{~A} / \mathrm{Y} 67 \mathrm{~A}$, and M80A/Y67H variants adsorbed on a polycrystalline gold electrode coated with a SAM of MUA/MU or 1-DT. For the solution composition, experimental conditions, and uncertainties associated with the reported values, the reader is referred to the original literature.

\begin{tabular}{|c|c|c|c|c|}
\hline & $K_{M}(\mu \mathrm{M})$ & $\begin{array}{c}J_{\max } \\
\left(\mu \mathrm{A} \mathrm{cm}^{-2}\right)\end{array}$ & $\begin{array}{c}J_{\max } / K_{M} \\
\left(\mu \mathrm{A} \mathrm{cm}^{-2} \mu \mathbf{M}^{-1}\right)\end{array}$ & Ref. \\
\hline \multicolumn{5}{|c|}{ Protein adsorbed on a Au electrode surface-modified with a MUA/MU SAM } \\
\hline wt ycc & - & - & - & \\
\hline wt ycc unfolded (8 M urea) & 9.3 & 5.18 & 0.56 & [102] \\
\hline K79A ycc unfolded (8 M urea) & 2.0 & 5.50 & 2.75 & [102] \\
\hline K73A ycc unfolded (8 M urea) & 18.8 & 2.68 & 0.14 & [102] \\
\hline K72A/K73A ycc unfolded (8 M urea) & 18.3 & 5.53 & 0.30 & [102] \\
\hline K72A/K73A/K79A ycc unfolded (8 M urea) & 11.5 & 2.34 & 0.20 & [102] \\
\hline K72A/H73H/K79A ycc folded (0 M urea), pH 7.4 & 0.95 & 0.5 & 0.5 & [38] \\
\hline K72A/H73H/K79A ycc unfolded (4 M urea), $\mathrm{pH} 7.4$ & 0.96 & 4.0 & 4.2 & {$[38]$} \\
\hline K72A/H73H/K79A ycc unfolded (8 M urea), pH 7.4 & 0.60 & 2.7 & 4.5 & [38] \\
\hline K72A/H73H/K79A ycc unfolded (8 M urea), pH 5 & 0.59 & 2.8 & 4.7 & {$[38]$} \\
\hline M80A yсc & 3.25 & 9.26 & 2.85 & [9] \\
\hline M80A ycc unfolded (7 M urea) & 1.38 & 5.49 & 3.98 & {$[44]$} \\
\hline M80A/Y67A yсc & 8.90 & 0.94 & 0.11 & [9] \\
\hline M80A/Y67A ycc unfolded (7 M urea) & 5.36 & 4.52 & 0.84 & {$[44]$} \\
\hline M80A/Y67H усс & 3.7 & 2.91 & 1.27 & [9] \\
\hline \multicolumn{5}{|c|}{ Protein adsorbed on a Au electrode surface-modified with a 1-DT SAM } \\
\hline wt bcc & 3.4 & 12.4 & 3.56 & [104] \\
\hline$w t b c c+C L$ & 4.1 & 17.3 & 4.22 & [104] \\
\hline wt ycc & 4.1 & 11.2 & 2.73 & [104] \\
\hline$y c c w t+C L$ & 4.9 & 16.5 & 3.37 & {$[104]$} \\
\hline K72A/K73A/K79А усс & 5.5 & 10.8 & 1.96 & [104] \\
\hline $\mathrm{K} 72 \mathrm{~A} / \mathrm{K} 73 \mathrm{~A} / \mathrm{K} 79 \mathrm{~A}+\mathrm{CL}$ & 6.2 & 15.1 & 2.44 & [104] \\
\hline M80A yсc & 4.72 & $3.76^{\mathrm{a}}$ & $0.80^{\mathrm{a}}$ & [39] \\
\hline M80A/Y67А усс & 2.80 & $4.73^{\mathrm{a}}$ & $1.69^{\mathrm{a}}$ & [39] \\
\hline $\mathrm{M} 80 \mathrm{~A}$ ycc +CL & 1.90 & $1.41^{\mathrm{a}}$ & $0.74^{\mathrm{a}}$ & [39] \\
\hline $\mathrm{M} 80 \mathrm{~A} / \mathrm{Y} 67 \mathrm{~A}$ ycc $+\mathrm{CL}$ & 2.01 & $3.64^{\mathrm{a}}$ & $1.81^{\mathrm{a}}$ & [39] \\
\hline
\end{tabular}

${ }^{\text {a }}$ Calculated by multiplying the data reported in Table 3 of ref. [39] by the corresponding electrode surface coverages $\Gamma_{0}$.

A similar approach can be extended to multi-heme proteins. In particular, the M64A and M164A variants of the di-heme cytochrome $c_{4}$ from P. haloplanktis, in which the Febinding methionine of both heme centers is replaced by an $\mathrm{OH}^{-}$ion, have been studied as potential components for third generation biosensors [40]. Indeed, the M64A mutant, thanks to a favorable orientation on a MUA-coated gold electrode, can act as catalyst for 
dioxygen reduction, while the native C-terminal heme most likely functions as an electron shuttle to the newly introduced catalytic center [40].

\section{Exploiting Protein Unfolding}

Cytochrome $c$ unfolds due to acidic $\mathrm{pH}$, denaturing agents (urea and $\mathrm{GdCl}$ ) or upon interaction with (mainly hydrophobic) surfaces [10,68,76,77,88,108,113,115,127,133-135]. In all cases, a remarkable decrease in $E^{\circ \prime}$ is observed, due to the replacement of Met80 by a new axial ligand (either an $\mathrm{OH}^{-}$ion or an endogenous His or Lys residue), which selectively stabilizes the ferric protein.

\subsection{Chemical Unfolding}

Cyclic voltammetric and Surface-enhanced resonance Raman (SERR) spectroscopy studies have shown that in the presence of high urea concentration $(>6 \mathrm{M})$ the $E^{\circ \prime}$ of beef heart and yeast cytcs, adsorbed on electrodes surface-modified with MUA/MU and 4-MP SAMs, shifts to approximately $0.4 \mathrm{~V}$ more negative values, owing to the replacement of the native Met80 axial ligand by His 26 or 33 [101,102,113,115,136]. In similar conditions, the same heme axial ligand swapping is also observed for single, double, and triple mutants of yeast cytc, in which the lysine residues surrounding the solvent-exposed heme edge (Figure 1) are replaced by alanines (K73A, K79A, K72A/K73A, and K72A/K73A/K79A variants) $[102,113]$.

In all cases, the adsorbed urea-unfolded proteins catalyze the reduction of $\mathrm{O}_{2}$ and $\mathrm{H}_{2} \mathrm{O}_{2}$ [101,102]. The unfolded bis-His ligated conformers, prevailing at large concentrations of unfolding agent $[101,102,113,136]$, are responsible for the observed behavior [101,102], since the native His-Met-ligated form of all immobilized proteins is unable to perform the electrocatalytic reduction of $\mathrm{O}_{2}$ and $\mathrm{H}_{2} \mathrm{O}_{2}$. Moreover, the protein layers are stable and can be re-used, as the voltammetric signal of all bis-His-ligated conformers can be restored upon complete removal of dioxygen and $\mathrm{H}_{2} \mathrm{O}_{2}$, and the catalytic currents can be reobtained upon addition of the substrates [101,102]. Most importantly, the near invariance of the cathodic and anodic peak potentials over the entire range of dioxygen partial pressures and hydrogen peroxide concentrations analyzed indicates that in all cases the catalytic active species is the ferrous form [101,102], which binds and reduces $\mathrm{O}_{2}$ and $\mathrm{H}_{2} \mathrm{O}_{2}$, as observed for different heme enzyme-based electrodes [5,6,22,137,138].

The lower affinity of the imidazole ring of histidine for the ferrous heme compared to the sulfur of the native Met 80 axial ligand is crucial, because it reduces the stability of the reduced bis-His-ligated conformer, inducing the dissociation of one of the histidine ligands from the iron(II) center [101,102], and thereby making an axial site available for the interaction with $\mathrm{O}_{2}$ and $\mathrm{H}_{2} \mathrm{O}_{2}$. On the contrary, the six-coordinate ferrous heme iron of folded wt cytc is not available for substrate binding, due to the strong bond formed with the thioether sulfur of the axial Met ligand.

The observed electrocatalytic activity of the bis-His-ligated cytc conformers towards $\mathrm{O}_{2}$ can be accounted for by a mechanism in which $\mathrm{O}_{2}$ binds to the ferrous heme upon dissociation of one of the axial His, yielding an oxidative addition that results in a $\mathrm{Fe}(\mathrm{III})-$ $\mathrm{O}_{2}{ }^{-}$derivative, which then dissociates [101]:

$$
\begin{gathered}
\text { cytc-Fe(III)-His }+\mathrm{e}^{-} \rightarrow \text { cytc-Fe(II) }---\mathrm{His} \\
\text { cytc-Fe(II) }---\mathrm{His}+\mathrm{O}_{2} \rightarrow \text { cytc-Fe(III)-O }{ }_{2}^{-} \\
\text {cytc-Fe(III)-O }{ }_{2}^{-} \rightarrow \text { cytc-Fe(III)-His }+\mathrm{O}_{2}{ }^{-}
\end{gathered}
$$

where cytc-Fe(II) - - - His is the ferrous unfolded yeast cytc, in which one of the metalHis bonds is longer and weakened. Detection of the superoxide ion in the products of the (electro)catalytic reduction confirms the soundness of the above mechanism [101].

Likewise, based on literature data showing that in several reactions iron (II) is oxidized to the ferryl group by $\mathrm{H}_{2} \mathrm{O}_{2}$ [139], the following mechanism is proposed for the observed 
electrocatalytic reduction of $\mathrm{H}_{2} \mathrm{O}_{2}$ mediated by the ferrous bis-His-ligated unfolded conformer [102]:

$$
\begin{gathered}
\text { cytc-Fe(III)-His }+\mathrm{e}^{-} \rightarrow \text { cytc-Fe(II) }--- \text { His } \\
\text { cytc-Fe(II) }--- \text { His }+\mathrm{H}_{2} \mathrm{O}_{2} \rightarrow \text { cytFe(IV) }=\mathrm{O}(\text { His })_{\text {uncoordinated }}+\mathrm{H}_{2} \mathrm{O} \\
\text { cytFe(IV) }=\mathrm{O}(\mathrm{His})_{\text {uncoordinated }}+\mathrm{e}^{-}+2 \mathrm{H}^{+} \rightarrow \text { cytc-Fe(III)-His }+\mathrm{H}_{2} \mathrm{O}
\end{gathered}
$$

Since the $E^{\circ /}$ of the ferryl group is remarkably more positive than that of the ferric heme, under the conditions of the catalytic event, the former is immediately reduced at the potential of the electrode [102].

The catalytic activity of electrode-immobilized unfolded His-His conformers in $9 \mathrm{M}$ urea was successfully estimated using the Michaelis-Menten model [102]. The data reported in Table 3 show that the urea unfolded His-His conformer of yeast cytc immobilized on both MUA/MU and 4-MP SAMs possesses a large catalytic efficiency for $\mathrm{O}_{2}$ reduction [101], which is only marginally affected by the nature of the protein-SAM interactions (electrostatic or through H-bonds). Since cytc unfolding has been associated with human pathologies and disorders involving increased production of partially reduced oxygen species, this result suggests that $\mathrm{O}_{2}$ adds to $\mathrm{H}_{2} \mathrm{O}_{2}$ as a substrate for catalytic reactions carried out by denatured cytc, which contributes to the overall oxidative stress of the cell [101].

Table 3. Kinetic parameters for the electrocatalytic reduction of $\mathrm{O}_{2}$ carried out by urea-unfolded bis-His form of yeast iso-1 cytochrome $c$ (ycc) adsorbed on a polycrystalline gold electrode coated with a SAM of MUA/MU or 4-MP. For the solution composition, experimental conditions, and uncertainties associated with the reported values, the reader is referred to the original literature.

\begin{tabular}{lccc}
\hline & $\left.\boldsymbol{K}_{\boldsymbol{M}} \mathbf{( P a}\right)$ & $J_{\max }\left(\mu \mathbf{A ~ \mathbf { ~ c m } ^ { - 2 } )}\right.$ & Ref. \\
\hline wt ycc adsorbed on MUA/MU & $2.39 \times 10^{4}$ & 4.75 & {$[101]$} \\
wt ycc adsorbed on 4-MP & $1.76 \times 10^{4}$ & 2.99 & {$[101]$} \\
\hline
\end{tabular}

As for $\mathrm{O}_{2}$, the $K_{M}$ and $j_{\max }$ values for the electrocatalytic reduction of $\mathrm{H}_{2} \mathrm{O}_{2}$ by the immobilized unfolded bis-His-ligated conformers of native cytc and the Lys-to-Ala mutants (Table 2) are indicative of a high catalytic efficiency [102]. In particular, the $K_{M}$ values are comparable to those of the M80A variant [9], and show that the kinetic affinity of $\mathrm{H}_{2} \mathrm{O}_{2}$ for the heme iron in these proteins is one to three orders of magnitude larger than those for other heme proteins immobilized on surface-modified electrodes [102].

Between $\mathrm{pH} 5$ and 7.5, the K72A/K73H/K79A mutant of yeast cytochrome $c$ undergoes a reversible, $\mathrm{pH}$-dependent, structural transition, in which the newly introduced His 73 replaces Met80 as the sixth axial heme iron at slightly alkaline $\mathrm{pH}$ values $[15,38,56,88,140,141]$. Upon immobilization on a MUA/MU surface-modified gold electrode, this folded His-His ${ }_{73}$-ligated conformer mediates the electrocatalytic reduction of $\mathrm{H}_{2} \mathrm{O}_{2}$ (Figure 5), according to the same catalytic mechanism discussed above for urea-unfolded species (Equation (5)) [15,38,102].

This further confirms that the catalytic activity of cytc requires that at least one of the axial coordination positions of the ferrous heme is free, or occupied by a weak ligand, to bind the substrate molecule. Most interestingly, as the His/Met ligated form prevailing below pH 5.5 is catalytically inactive, the pseudo-peroxidase activity of the $\mathrm{K} 72 \mathrm{~A} / \mathrm{K} 73 \mathrm{H} / \mathrm{K} 79 \mathrm{~A}$ mutant can be turned on and off at will, by simply adjusting the $\mathrm{pH}$ within a small range around the physiological conditions [15]. The Michaelis-Menten equation yielded $j_{\max }$ and $K_{M}$ values of $0.5 \mu \mathrm{A} \mathrm{cm}^{-2}$ and $0.95 \mu \mathrm{M}$ for the folded His-His73ligated conformer (Table 2), respectively [15]. 


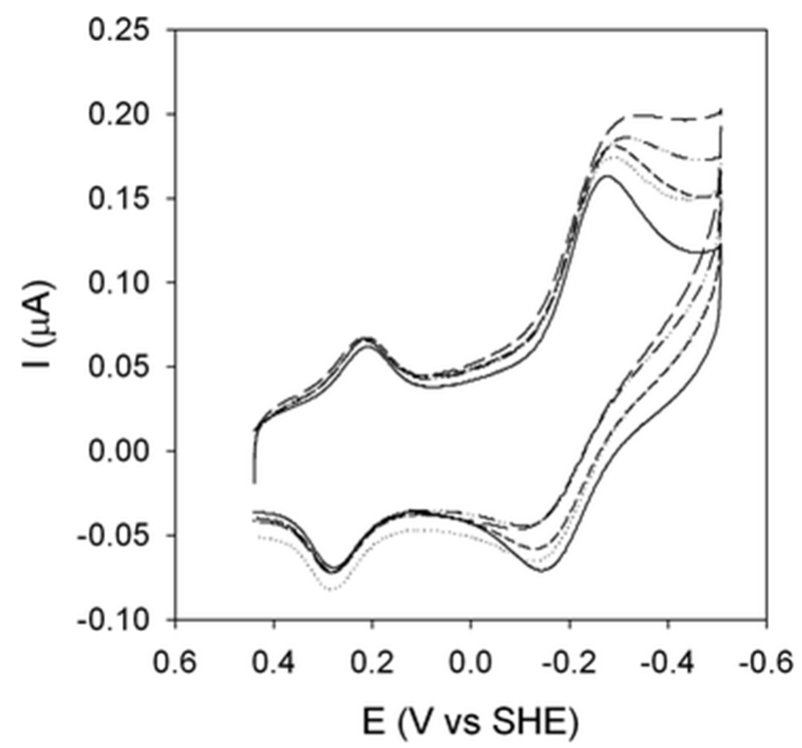

Figure 5. Cyclic voltammograms for a K72A/K73H/K79A mutant of yeast cytochrome $c$ adsorbed on polycrystalline gold electrode modified with a SAM of MUA/MU recorded in the presence of increasing concentrations of $\mathrm{H}_{2} \mathrm{O}_{2}$. For the solution composition and other experimental conditions, the reader is referred to the original literature. Reprinted with permission from ref. [15]. Copyright 2012 Royal Society of Chemistry.

Both the electrode-immobilized folded His-His 73 and His/Met conformers of the K72A/K73H/K79A mutant experience urea-induced unfolding [38]. The former species undergoes a conformational change above $5 \mathrm{M}$ urea, involving the replacement of His73 by another endogenous His (His26 or 33) as an axial iron ligand [38]. The axial Met80 of the latter form is proposed to be replaced by the engineered His73 at low urea concentrations, which in turn is replaced by another His ligand at larger denaturant concentrations [38]. Both unfolded bis-His ligated conformers observed at high urea concentrations feature nearly coincident reduction thermodynamics, rate of heterogeneous ET, and catalytic efficiency, indicating that they correspond to the same protein form [38]. The unfoldinginduced increased solvent accessibility of the heme in these systems results in a much higher catalytic efficiency compared to the folded His-His73-ligated species observed at $\mathrm{pH} 7.4$ in the absence of denaturant (Table 2). Their lower $K_{M}$ is consistent with the different His axial ligand, which apparently binds to the heme center more weakly than His73, increasing the heme affinity for $\mathrm{H}_{2} \mathrm{O}_{2}$ [38]. Likewise, the unfolded bis-His ligated conformers of the $\mathrm{K} 72 \mathrm{~A} / \mathrm{K} 73 \mathrm{H} / \mathrm{K} 79 \mathrm{~A}$ mutant feature much lower $K_{M}$ values than the urea-unfolded wt cytc and KtoA variants (Table 2), which indicates the easier access to the heme by $\mathrm{H}_{2} \mathrm{O}_{2}$ and suggests slightly different heme environments [38]. Most importantly, the observed decrease in $\mathrm{K}_{\mathrm{M}}$ results in a much higher catalytic efficiency.

\subsection{Adsorption-Induced Unfolding}

Immobilization on a hydrophobic SAM of decane-1-thiol (1-DT) induces the unfolding of wt and KtoA mutated cytc, resulting in an equilibrium between low-potential (LP) and high-potential (HP) conformers [103,104]. Surface-enhanced resonance Raman (SERR) spectra demonstrated that the LP and HP species contain a low-spin (LS) six-coordinated His-His and a high-spin (HS) five-coordinated His / - heme, respectively [103]. This assignment is supported by the corresponding $E^{\circ \prime}$ values, since the reduction potential of the LP conformer resembles those of the His-His ligated urea-unfolded cytc [101,102,113,115,136] and diheme cytochrome $c$ (DHC) from Shewanella baltica OS155 [142], whereas the $E^{\circ \prime}$ of the HP conformer is similar than that of immobilized myoglobin, featuring a five-coordinated high-spin His / - ligated heme [143]. Moreover, the LS six-coordinated His-His ligation 
prevails in the oxidized state, whereas the HS five-coordinated His / - heme prevails in the reduced form $[103,104]$.

Gold electrodes modified with a SAM of decane-1-thiol (1-DT) were used to study the effect of hydrophobic immobilization on the redox behavior of the adduct formed by wt and KtoA cytc with cardiolipin (CL) [103,104], a negatively charged glycerophospholipid found in the inner mitochondrial membrane (IMM) $[48,57,62,68,75,77,93,106,107]$. Binding of cytc to $C L$ in vivo blocks the mitochondrial electron transfer chain and imparts the protein with a significant (lipo)peroxidase activity $[48,57,68,75,77,93,97,100,106,107]$. CL peroxidation catalyzed by CL-bound cytc increases the permeability of the mitochondrial membrane, allowing cytc ejection into the cytosol, where it promotes the apoptosis cascade, upon forming a multimeric complex (apoptosome) with Apaf-1 (Apoptotic protease activating factor 1), ATP, and pro-caspase-9 $[48,57,68,75,77,93,106,107]$. The interaction between cytc and $C L$ has been widely investigated in solution, revealing that formation of the cytc-CL adduct induces a relevant conformational change, which includes swapping of the axial methionine ligand $[48,57,62,68,75,77,93,95-97,100,106,107,144]$.

Although not strictly relevant for biosensing, hydrophobic immobilization of the cytc-CL adduct provides important bio-physical information, since it mimics the motional restriction experienced by cytc upon binding to CL at IMM and it conceivably would more closely reproduce the in vivo behavior than the studies carried out in solution [103,104]. Moreover, the extended and smoothed surface of the SAM of 1-DT is more similar to the IMM surface compared to a small, soft, and approximately spherical liposome in solution $[103,104]$, since the protein density on the phospholipidic membrane and its curvature heavily affect the cytc-CL interaction [68,92].

Adsorption of cytc-CL adducts on the hydrophobic SAM of decane-1-thiol results in the equilibrium between the same low-potential (LP) low-spin six-coordinated His-His and high-potential (HP) high-spin five-coordinated His / - conformers observed without CL, prevailing in the oxidized and reduced states, respectively [103,104]. Interestingly, CL binding makes the conversion between the LP and HP conformers faster. This behavior is similar to that observed upon the cytc binding to liposomes formed by $100 \% \mathrm{CL}$ or by a combination of 1,1',1,2'-tetraoleyolcardiolipin (TOCL, 20\%) and 1,2-deoleyol-snglycero-3phosphocholine (DOPC, 80\%) using different spectroscopic techniques $[95,109]$.

Upon increasing the concentration of $\mathrm{O}_{2}$ (by increasing the time of exposure of the electrochemical cell, initially under argon, to air) [103] and $\mathrm{H}_{2} \mathrm{O}_{2}$ [104], the current of the cathodic peak of the LP His-His species invariably increases, with almost no change in peak potential, as observed for the urea-unfolded wt and KtoA cytc immobilized on anionic and hydrophilic SAMs [101,102]. This demonstrates that the ferrous LP conformer can mediate the electrocatalytic reduction of $\mathrm{O}_{2}$ and $\mathrm{H}_{2} \mathrm{O}_{2}$, according to the same catalytic mechanisms discussed above for urea-unfolded species (Equations (4) and (5), respectively), which assume the dissociation of one of the axial His from the iron(II) center. Unfortunately, the cathodic peak of the HP conformer is barely detectable in the applied experimental conditions and cannot be considered in the analysis of the observed electrocatalytic activity $[103,104]$. The catalytic activity of free and CL-bound cytc immobilized on the SAM of decane-1-thiol (1-DT) for the reduction of $\mathrm{H}_{2} \mathrm{O}_{2}$ can be estimated using the usual Michaelis-Menten approach, yielding $K_{M}$ and $j_{\max }$ values comparable to those of urea-unfolded wt and KtoA cytc immobilized on negatively charged SAMs (Table 2). The CL adducts invariably feature a slightly higher electrocatalytic efficiency, due to an increased $K_{M}$ and $j_{\max }$ [104]. Hence, in the presence of CL, a slight decrease in the accessibility of the catalytic center is observed, whereas a larger $j_{\max }$ should reflect an enhancement of $k_{c a t}$.

Since high concentrations of $\mathrm{O}_{2}{ }^{-}$can trigger cell death, and spontaneous bursts of superoxide generation in mitochondria are early signals initiating oxidative stress-related apoptosis [103]; the ability to catalytically reduce $\mathrm{O}_{2}$ to $\mathrm{O}_{2}{ }^{-}$conferred on the cytc/CL adducts by immobilization on 1-DT can be physiologically relevant, possibly suggesting a direct involvement of cytc and $\mathrm{O}_{2}$ in superoxide ion generation during pre-apoptotic processes in mitochondria [103]. 


\section{Combining Point Mutations with Unfolding}

The M80A and M80A/Y67A variants of yeast cytc were immobilized on a MUA/MU modified Au electrode and denatured with urea [44]. SERR spectra show that the two immobilized (folded) mutants contain a low-spin six-coordinate heme, the axial coordination positions of which are occupied by the proximal His residue and a hydroxide ion [44], as observed in solution $[9,37,122,123,127]$. The same heme axial coordination is maintained upon urea-induced unfolding at neutral $\mathrm{pH}$, although an increased accessibility of the heme pocket to the solvent is observed [44]. Most importantly, the two immobilized mutants can catalyze the reduction of $\mathrm{H}_{2} \mathrm{O}_{2}$ (pseudo-peroxidase activity) and $\mathrm{NO}_{2}{ }^{-}$(nitritereductase activity), in both folded and urea-unfolded states [44]. As observed for other mutant/surface combinations, the electrocatalytic activity towards $\mathrm{H}_{2} \mathrm{O}_{2}$ was irreversibly lost for substrate concentrations above $7 \mu \mathrm{M}$, while at lower concentrations the adduct was found to be both reusable and stable, which are crucial requirements for operation in real life scenarios. The $K_{M}$ values for the pseudo-peroxidase activity were 1.38 and $5.36 \mu \mathrm{M}$ for the urea-unfolded M80A and M80A/Y67A, respectively [44], which are both lower than the corresponding values for the folded mutants in the absence of urea (Table 2). This finding was ascribed to an increased kinetic instability of the Fe(III)-hydroperoxide complex that should be formed during the catalytic cycle, which is also responsible for the larger catalytic activity of the unfolded immobilized mutants compared to the folded species, as indicated by their larger $j_{\max } / K_{M}$ ratios [44]. On the contrary, the opposite effects of urea unfolding on the $j_{\max }$ of the two mutants could not be unambiguously explained.

Moreover, with respect to the nitrite-reductase activity observed with $\mathrm{NO}_{2}{ }^{-}$concentrations in the 1-6 $\mu \mathrm{M}$ range, urea-induced unfolding yields a decrease in $K_{M}$ if compared to the folded species (Table 1). This finding can again be explained by invoking the higher accessibility of the heme iron to exogenous substrates [92]. The effect is more pronounced for M80A than for M80A/Y67A, with the latter displaying much lower kinetic instability, most likely due to a more hydrophobic catalytic pocket (following the Tyr-to-Ala mutation) that impacts on the accessibility to the ionic substrate [44].

Upon immobilization on gold electrodes modified with a SAM of decane-1-thiol, the M80A and M80A/Y67A yeast cytc mutants and their CL-adducts show the same behavior as the wt protein and its triple KtoA in the same conditions [39]. In particular, the same low potential (LP) low-spin six-coordinated His/His and high potential (HP) high-spin five-coordinated His/ - conformers are observed, which are more stable in the oxidized and reduced states, respectively [39]. Hence, immobilization on the hydrophobic surface invariably results in the release of the $\mathrm{OH}^{-}$ion, which replaces the native Met80 as heme axial ligand in both mutants, either in solution or electrostatically bound to a negatively charged SAM of MUA/MU [44]. Interestingly, the interconversion of the LS 6c His/His (LP) species to the HS 5c His/- (HP) conformer is favored by increasing temperature [39]. This effect was not observed for the wt protein and its triple KtoA mutant $[103,104]$. Overall, the above results indicate that (i) the heme axial ligation in free or CL-bound M80A and M80/Y67A immobilized on a hydrophobic surface is different from that observed in solution and upon electrostatic immobilization on a MUA/MU SAM, and (ii) the coordination of the heme center in both mutants is not appreciably affected by CL binding [39].

In the presence of micromolar concentrations of $\mathrm{H}_{2} \mathrm{O}_{2}$ and $\mathrm{NO}_{2}{ }^{-}$, the M80A and M80A/Y67A mutants and their CL-adducts immobilized on decane-1-thiol-modified Au electrodes show good pseudo-peroxidase and nitrite-reductase activities, which are observed up to $\mathrm{H}_{2} \mathrm{O}_{2}$ and $\mathrm{NO}_{2}{ }^{-}$concentrations of about $5 \mu \mathrm{M}$ and $1.75 \mu \mathrm{M}$, respectively [39]. Below these concentrations, elimination of substrates restores the voltammetric signal of the protein, while catalytic currents could be re-obtained upon addition of hydrogen peroxide and sodium nitrite. Hence, under the applied conditions, the protein layer is stable and re-usable.

For both substrates, the ferrous His/His-ligated forms are the catalytically active species, indicating that their catalytic reduction by M80A and M80A/Y67A immobilized 
on 1-DT requires detachment of the 6th His ligand from the Fe(II) heme [39]. Therefore, the catalytic mechanism for $\mathrm{H}_{2} \mathrm{O}_{2}$ reduction is the same as suggested for wt cytc and its triple KtoA variant subjected to the same immobilization [90], while the following mechanism is proposed for $\mathrm{NO}_{2}{ }^{-}$reduction [39]:

$$
\begin{gathered}
\text { cytc-Fe(III)-His }+\mathrm{e}^{-} \rightarrow \text { cytc-Fe(II) }--- \text { His } \\
\text { cytc-Fe(II) }--- \text { His }+\mathrm{NO}_{2}{ }^{-}+\mathrm{H}_{2} \mathrm{O} \rightarrow \text { cytFe(III)-His }+\mathrm{NO}+2 \mathrm{OH}^{-}
\end{gathered}
$$

The usual approach based on the Michaelis-Menten equation expressed in terms of current density is used to estimate the catalytic activity of free and CL-bound M80A and M80A/Y67A immobilized on the SAM of decane-1-thiol (1-DT) for $\mathrm{H}_{2} \mathrm{O}_{2}$ and $\mathrm{NO}_{2}{ }^{-}$ reduction. The resulting $K_{M}$ for both substrates are sensibly larger than those for other immobilized heme proteins (Tables 1 and 2) and the $K_{M}$ for $\mathrm{H}_{2} \mathrm{O}_{2}$ are comparable to those of wt cyt and its triple KtoA mutant (Table 2).

The effects on the electrocatalytic activity of the mutation(s) within the heme site and CL binding are reaction-specific (Figure 6). For hydrogen peroxide reduction, the different hydrogen bonding network within the heme crevice disfavors access of the substrate to the heme iron in the M80A mutant and facilitates it in the M80A/Y67A species, resulting in a larger and a lower $K_{M}$ compared to the wild type protein (Table 2) [39]. Likewise, the different heme environment is responsible for the opposite effect being exerted by CL binding on the $K_{M}$ of wt cytc and the two mutants (Figure 6). It is important to stress that the observed nitrite-reductase activity results from the M80A mutation, since the wt protein is catalytically inactive [39] (Figure 6 and Table 1). Contrary to the pseudoperoxidase reaction, the $K_{M}$ value for nitrite reduction increases upon addition of the Y67A mutation and/or formation of the CL-adducts (Figure 6 and Table 1), possibly reflecting the enhanced hydrophobicity of the heme crevice, which would hamper the access of the negatively charged $\mathrm{NO}_{2}{ }^{-}$to the metal center [39].

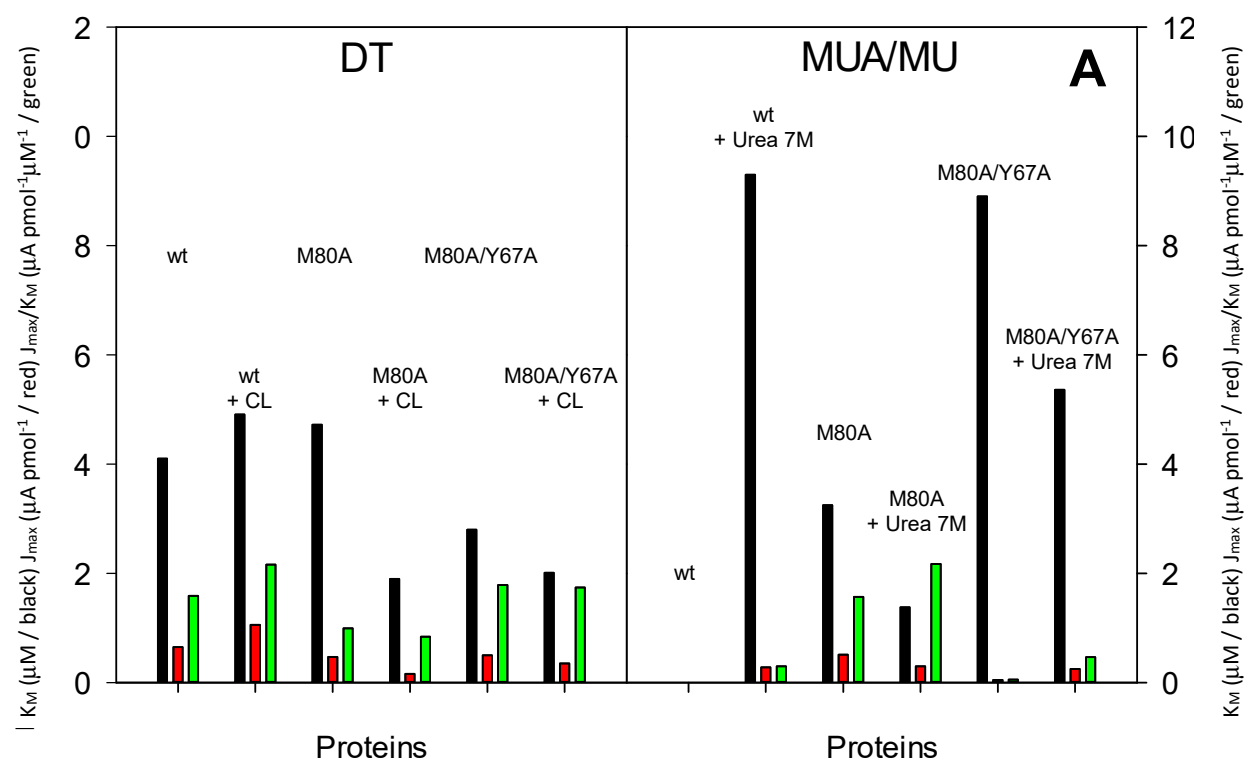

Figure 6. Cont. 


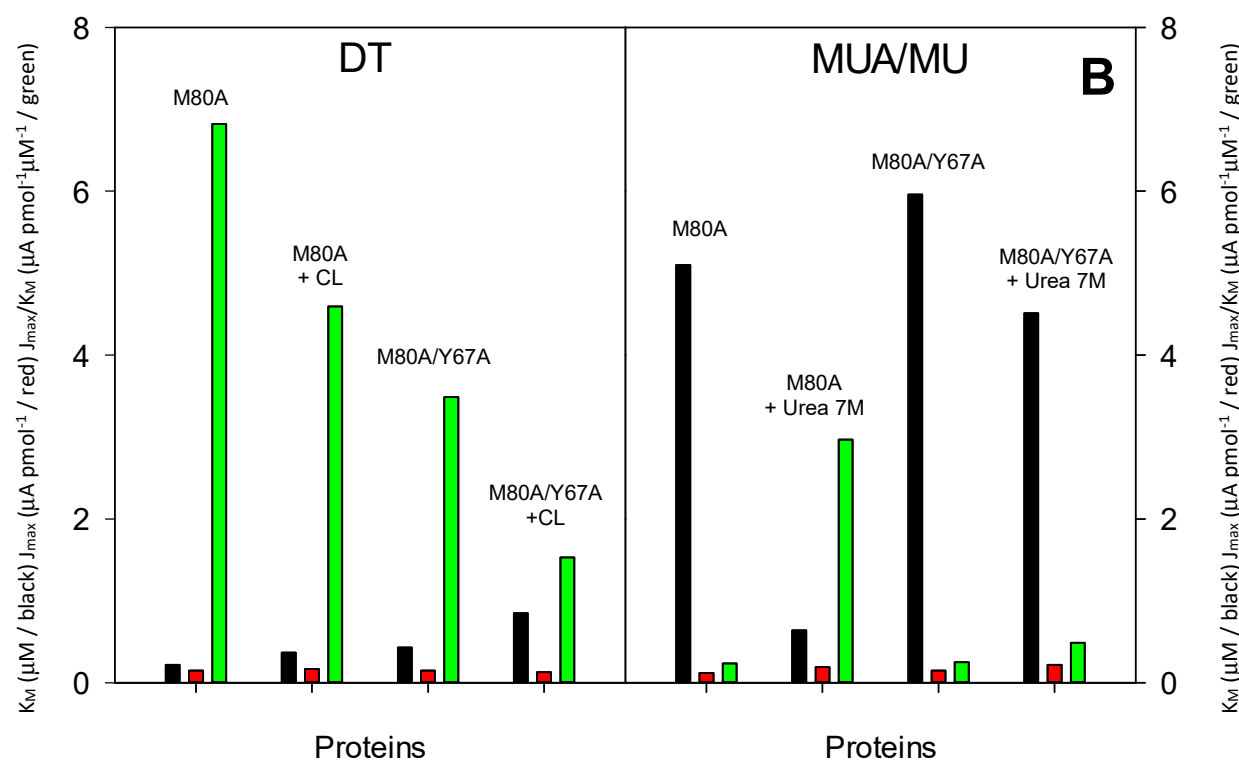

Figure 6. Histograms depicting the $K_{M}\left(\mu \mathrm{M}\right.$, black bar), $J_{\max }\left(\mu \mathrm{A} \mathrm{pmol}{ }^{-1}\right.$, red bar) and $J_{\max } / K_{M} \times 10$ ( $\mu \mathrm{A} \mathrm{pmol}{ }^{-1} \mu \mathrm{M}^{-1}$, green bar) values for the reductive electrocatalysis of $(\mathbf{A}) \mathrm{H}_{2} \mathrm{O}_{2}$ and $(\mathbf{B}) \mathrm{NO}_{2}{ }^{-}$, carried out by wt yeast iso- 1 cytochrome $c$ and its M80A and M80A/Y67A variants immobilized on a gold electrode functionalized with a hydrophobic SAM of decane-1-thiol (DT) and a negatively charged SAM of MUA/MU, along with the corresponding adducts with cardiolipin (this work) and the same species in $7 \mathrm{M}$ urea immobilized under the same conditions. Figure (A left frame): 1, wt; 2, wt + CL, 3, M80A; 4, M80A + CL; 5, M80A/Y67A; 6, M80A/Y67A + CL. Figure (A right frame): 1, wt; 2, wt + Urea 7M, 3, M80A; 4, M80A + Urea 7M; 5, M80A/Y67A; 6, M80A/Y67A + Urea 7M. Figure (B left frame): 1, M80A; 2, M80A + CL; 3, M80A/Y67A; 4, M80A/Y67A + CL. Figure (B right frame): 1, M80A; 2, M80A + Urea 7M; 3, M80A/Y67A; 4, M80A/Y67A + Urea 7M. Reprinted with permission from ref. [39]. Copyright 2020 Elsevier.

Comparison of the data reported in Tables 1 and 2 unequivocally demonstrates that the electrocatalytic ability of wt cytc and its M80A and M80A/Y67A mutants is strongly affected by the nature of the SAM used for protein immobilization. In particular, the absence of pseudo-peroxidase activity for wt yeast cytc on MUA/MU SAM [102] is related to the persistence of the Met-Fe(II) axial bond, which hampers substrate binding, whereas the weaker and more labile His-Fe(II) bond observed upon immobilization on DT allows for $\mathrm{H}_{2} \mathrm{O}_{2}$ binding and turnover [39]. On the other hand, the different mutation-induced changes in the catalytic activity observed for the same species upon immobilization on the two different SAMs show that the influence of protein-SAM interactions on protein conformation extends to the H-bonding network, polarity, solvation, and electrostatics of the heme environment [39].

\section{Conclusions}

We have shown that two main routes can be followed to turn cytochrome $c$ into a redox enzyme to be immobilized on an electrode for biosensing applications. The first is the design and production of ad hoc designed mutants. To this end, the most widely explored mutation has been the substitution of the axial heme iron ligand Met80 into a non-coordinating alanine to yield a free position in the iron coordination sphere $[8,9,37]$. Other mutations have been explored, mainly aimed at altering the hydrogen bond network in the heme pocket (Tyr67) [9] or introducing a His residue on the protein surface (Lys73) that can serve as weak axial ligand in a $\mathrm{pH}$-switchable, low potential conformer $[15,38]$.

The second strategy is to unfold cytc. In this respect, urea-induced unfolding has been often preferred, generating a His-His conformer possessing catalytic properties absent in the folded species $[101,102]$. Cytc can also be turned into a redox enzyme upon 
immobilization on a hydrophobic SAM $[103,104]$. Moreover, site directed mutagenesis and chemical- or adsorption-induced unfolding can also be used in synergy $[39,44]$. Dioxygen, hydrogen peroxide, and nitrite anions are the three main substrates that have been successfully investigated. The catalytic activity of the novel, non-native species have been described using the Michaelis-Menten equation, expressed in terms of current density $[8,9,15,38,39,44,101,102,104]$. The combination of the main structural features of cytc (e.g., a covalently bound heme, stability over a large range of conditions) with the enzymatic properties introduced ad hoc make this protein a strong candidate for biosensing applications, provided the issues related to its lower catalytic activity and selectivity compared to redox enzymes can be effectively solved.

Author Contributions: Conceptualization: C.A.B., G.B.; writing—review and editing: A.R., M.B., S.C., G.D.R., M.S., C.A.B., G.B.; writing—original draft preparation: C.A.B., G.B.; funding acquisition: M.B., S.C., M.S., G.B. All authors have read and agreed to the published version of the manuscript.

Funding: This research was funded by the University of Modena and Reggio Emilia FAR 2020 DSCG (M.B), FAR 2020-DSV (M.S.), FAR 2020-Impulso (G.B.) funding programs. S.C. acknowledges the fundings from the University of Padua, Department of Chemical Sciences (P-DiSC\#11NExuS _BIRD2020-UNIPD-CARBON-FET-) and from the Italian Ministry of Education, Universities and Research (Nanochemistry for Energy and Health, NExuS, within the national funding network termed "Dipartimenti di Eccellenza").

Institutional Review Board Statement: Not applicable.

Informed Consent Statement: Not applicable.

Data Availability Statement: No new data were created or analyzed in this study. Data sharing is not applicable to this article.

Conflicts of Interest: The authors declare no conflict of interest.

\section{References}

1. Cowan, J.A. Inorganic Biochemistry: An introduction, 2nd ed.; Wiley-VCH: New York, NY, USA, 1997; ISBN 978-0-471-18895-7.

2. Lippard, S.J.; Berg, J.M. Principle of Bioinorganic Chemistry; University Science Books: Mill Valley, CA, USA, 1994 ; ISBN 0-935702-73-3.

3. Poulos, T.L. Heme enzyme structure and function. Chem. Rev. 2014, 114, 3919-3962. [CrossRef] [PubMed]

4. Shimizu, T.; Lengalova, A.; Martínek, V.; Martínková, M. Heme: Emergent roles of heme in signal transduction, functional regulation and as catalytic centres. Chem. Soc. Rev. 2019, 48, 5624-5657. [CrossRef] [PubMed]

5. Ranieri, A.; Bortolotti, C.A.; Di Rocco, G.; Battistuzzi, G.; Sola, M.; Borsari, M. Electrocatalytic Properties of Immobilized Heme Proteins: Basic Principles and Applications. ChemElectroChem 2019, 6, 5172-5185. [CrossRef]

6. Zuccarello, L.; Barbosa, C.; Todorovic, S.; Silveira, C.M. Electrocatalysis by heme enzymes-Applications in biosensing. Catalysts 2021, 11, 218. [CrossRef]

7. Li, T.; Bonkovsky, H.L.; Guo, J.T. Structural analysis of heme proteins: Implications for design and prediction. BMC Struct. Biol. 2011, 11, 13. [CrossRef] [PubMed]

8. Casalini, S.; Battistuzzi, G.; Borsari, M.; Ranieri, A.; Sola, M. Catalytic Reduction of Dioxygen and Nitrite Ion at a Met80Ala Cytochrome c-Functionalized Electrode. J. Am. Chem. Soc. 2008, 130, 15099-15104. [CrossRef]

9. Casalini, S.; Battistuzzi, G.; Borsari, M.; Bortolotti, C.A.; Di Rocco, G.; Ranieri, A.; Sola, M. Electron transfer properties and hydrogen peroxide electrocatalysis of cytochrome $c$ variants at positions 67 and 80 . J. Phys. Chem. B 2010, 114, 1698-1706. [CrossRef]

10. Silveira, C.M.; Castro, M.A.; Dantas, J.M.; Salgueiro, C.; Murgida, D.H.; Todorovic, S. Structure, electrocatalysis and dynamics of immobilized cytochrome PccH and its microperoxidase. Phys. Chem. Chem. Phys. 2017, 19, 8908-8918. [CrossRef]

11. Aghamiri, Z.S.; Mohsennia, M.; Rafiee-Pour, H.A. Immobilization of cytochrome $c$ and its application as electrochemical biosensors. Talanta 2018, 176, 195-207. [CrossRef]

12. Ferapontova, E.E.; Castillo, J.; Gorton, L. Bioelectrocatalytic properties of lignin peroxidase from Phanerochaete chrysosporium in reactions with phenols, catechols and lignin-model compounds. Biochim. Biophys. Acta Gen. Subj. 2006, 1760, 1343-1354. [CrossRef]

13. Barbosa, C.; Silveira, C.M.; Silva, D.; Brissos, V.; Hildebrandt, P.; Martins, L.O.; Todorovic, S. Immobilized dye-decolorizing peroxidase (DyP) and directed evolution variants for hydrogen peroxide biosensing. Biosens. Bioelectron. 2020, $153,112055$. [CrossRef]

14. Moyo, M.; Okonkwo, J.O.; Agyei, N.M. A novel hydrogen peroxide biosensor based on adsorption of horseradish peroxidase onto a nanobiomaterial composite modified glassy carbon electrode. Electroanalysis 2013, 25, 1946-1954. [CrossRef] 
15. Bortolotti, C.A.; Paltrinieri, L.; Monari, S.; Ranieri, A.; Borsari, M.; Battistuzzi, G.; Sola, M. A surface-immobilized cytochrome $c$ variant provides a pH-controlled molecular switch. Chem. Sci. 2012, 3, 807-810. [CrossRef]

16. De Groot, M.T.; Merkx, M.; Koper, M.T.M. Heme release in myoglobin-DDAB films and its role in electrochemical NO reduction. J. Am. Chem. Soc. 2005, 127, 16224-16232. [CrossRef] [PubMed]

17. Todorovic, S.; Jung, C.; Hildebrandt, P.; Murgida, D.H. Conformational transitions and redox potential shifts of cytochrome P450 induced by immobilization. J. Biol. Inorg. Chem. 2006, 11, 119-127. [CrossRef] [PubMed]

18. Brusova, Z.; Gorton, L.; Magner, E. Comment on “Direct Electrochemistry and Electrocatalysis of Heme Proteins Entrapped in Agarose Hydrogel Films in Room-Temperature Ionic Liquids". Langmuir 2006, 22, 11453-11455. [CrossRef]

19. Sassolas, A.; Blum, L.J.; Leca-Bouvier, B.D. Immobilization strategies to develop enzymatic biosensors. Biotechnol. Adv. 2012, 30, 489-511. [CrossRef] [PubMed]

20. Ronkainen, N.J.; Halsall, H.B.; Heineman, W.R. Electrochemical biosensors. Chem. Soc. Rev. 2010, 39, 1747-1763. [CrossRef]

21. Kaur, J.; Choudhary, S.; Chaudhari, R.; Jayant, R.D.; Joshi, A. 9-Enzyme-based biosensors. In Bioelectronics and Medical Devices; Pal, K., Kraatz, H.-B., Khasnobish, A., Bag, S., Banerjee, I., Kuruganti, U., Eds.; Woodhead Publishing: Sawston, UK, 2019; pp. 211-240. ISBN 978-0-08-102420-1.

22. Rusling, J.F. Enzyme Bioelectrochemistry in Cast Biomembrane-Like Films. Acc. Chem. Res. 1998, 31, 363-369. [CrossRef]

23. Léger, C.; Bertrand, P. Direct electrochemistry of redox enzymes as a tool for mechanistic studies. Chem. Rev. 2008, 108, 2379-2438. [CrossRef]

24. Murgida, D.H.; Hildebrandt, P. Redox and redox-coupled processes of heme proteins and enzymes at electrochemical interfaces. Phys. Chem. Chem. Phys. 2005, 7, 3773-3784. [CrossRef] [PubMed]

25. Nöll, T.; Nöll, G. Strategies for "wiring" redox-active proteins to electrodes and applications in biosensors, biofuel cells, and nanotechnology. Chem. Soc. Rev. 2011, 40, 3564-3576. [CrossRef]

26. Borgmann, S.; Hartwich, G.; Schulte, A.; Schuhmann, W. Amperometric Enzyme Sensors based on Direct and Mediated Electron Transfer. In Electrochemistry of Nucleic Acids and Proteins-Towards Electrochemical Sensors for Genomics and Proteomics; Paleček, E., Scheller, F., Wang, J., Eds.; Elsevier: Amsterdam, The Netherlands, 2005; Volume 1, pp. 599-655. ISBN 1871-0069.

27. Steen Redeker, E.; Ta, D.T.; Cortens, D.; Billen, B.; Guedens, W.; Adriaensens, P. Protein Engineering for Directed Immobilization. Bioconjug. Chem. 2013, 24, 1761-1777. [CrossRef]

28. Song, Y.; Liu, H.; Wan, L.; Wang, Y.; Hou, H.; Wang, L. Direct Electrochemistry of Cytochrome $c$ Based on Poly (diallyldimethylammonium Chloride)-Graphene Nanosheets/Gold Nanoparticles Hybrid Nanocomposites and Its Biosensing. Electroanalysis 2013, 25, 1400-1409. [CrossRef]

29. Guo, C.; Wang, J.; Chen, X.; Li, Y.; Wu, L.; Zhang, J.; Tao, C.A. Construction of a biosensor based on a combination of cytochrome C, graphene, and gold nanoparticles. Sensors 2019, 19, 40. [CrossRef] [PubMed]

30. Wang, Z.; Li, M.; Su, P.; Zhang, Y.; Shen, Y.; Han, D.; Ivaska, A.; Niu, L. Direct electron transfer of horseradish peroxidase and its electrocatalysis based on carbon nanotube/thionine/gold composites. Electrochem. Commun. 2008, 10, 306-310. [CrossRef]

31. Tian, J.; Wang, J.; Li, Y.; Huang, M.; Lu, J. Electrochemically Driven Omeprazole Metabolism via Cytochrome P450 Assembled on the Nanocomposites of Ceria Nanoparticles and Graphene. J. Electrochem. Soc. 2017, 164, H470-H476. [CrossRef]

32. Watanabe, Y.; Ueno, T. Introduction of P450, Peroxidase, and Catalase Activities into Myoglobin by Site-Directed Mutagenesis: Diverse Reactivities of Compound I. Bull. Chem. Soc. Jpn. 2003, 76, 1309-1322. [CrossRef]

33. Ozaki, S.I.; Matsui, T.; Roach, M.P.; Watanabe, Y. Rational molecular design of a catalytic site: Engineering of catalytic functions to the myoglobin active site framework. Coord. Chem. Rev. 2000, 198, 39-59. [CrossRef]

34. Xu, J.; Shoji, O.; Fujishiro, T.; Ohki, T.; Ueno, T.; Watanabe, Y. Construction of biocatalysts using the myoglobin scaffold for the synthesis of indigo from indole. Catal. Sci. Technol. 2012, 2, 739-744. [CrossRef]

35. Chand, S.; Ray, S.; Yadav, P.; Samanta, S.; Pierce, B.S.; Perera, R. Abiological catalysis by myoglobin mutant with a genetically incorporated unnatural amino acid. Biochem. J. 2021, 478, 1795-1808. [CrossRef]

36. Roncone, R.; Monzani, E.; Murtas, M.; Battaini, G.; Pennati, A.; Sanangelantoni, A.M.; Zuccotti, S.; Bolognesi, M.; Casella, L. Engineering peroxidase activity in myoglobin: The haem cavity structure and peroxide activation in the T67R/S92D mutant and its derivative reconstituted with protohaemin-L-histidine. Biochem. J. 2004, 377, 717-724. [CrossRef]

37. Casalini, S.; Battistuzzi, G.; Borsari, M.; Bortolotti, C.A.; Ranieri, A.; Sola, M. Electron Transfer and Electrocatalytic Properties of the Immobilized Methionine80Alanine Cytochrome $c$ Variant. J. Phys. Chem. B 2008, 112, 1555-1563. [CrossRef]

38. Ranieri, A.; Bortolotti, C.A.; Battistuzzi, G.; Borsari, M.; Paltrinieri, L.; Di Rocco, G.; Sola, M. Effect of motional restriction on the unfolding properties of a cytochrome $c$ featuring a His/Met-His/His ligation switch. Metallomics 2014, 6, 874. [CrossRef] [PubMed]

39. Lancellotti, L.; Borsari, M.; Bonifacio, A.; Bortolotti, C.A.; Di Rocco, G.; Casalini, S.; Ranieri, A.; Battistuzzi, G.; Sola, M. Adsorbing surface strongly influences the pseudo-peroxidase and nitrite reductase activity of electrode-bound yeast cytochrome c. The effect of hydrophobic immobilization. Bioelectrochemistry 2020, 136, 107628. [CrossRef] [PubMed]

40. Monari, S.; Battistuzzi, G.; Borsari, M.; Di Rocco, G.; Martini, L.; Ranieri, A.; Sola, M. Heterogeneous Electron Transfer of a Two-Centered Heme Protein: Redox and Electrocatalytic Properties of Surface-Immobilized Cytochrome c 4. J. Phys. Chem. B 2009, 113, 13645-13653. [CrossRef]

41. Diederix, R.E.M.; Ubbink, M.; Canters, G.W. Peroxidase activity as a tool for studying the folding of c-type cytochromes. Biochemistry 2002, 41, 13067-13077. [CrossRef] [PubMed] 
42. Diederix, R.E.M.; Ubbink, M.; Canters, G.W. Effect of the protein matrix of cytochrome $c$ in suppressing the inherent peroxidase activity of its heme prosthetic group. ChemBioChem 2002, 3, 110-112. [CrossRef]

43. Diederix, R.E.M.; Fittipaldi, M.; Worrall, J.A.R.; Huber, M.; Ubbink, M.; Canters, G.W. Kinetic Stability of the Peroxidase Activity of Unfolded Cytochrome c: Heme Degradation and Catalyst Inactivation by Hydrogen Peroxide. Inorg. Chem. 2003, 42, $7249-7257$. [CrossRef] [PubMed]

44. Lancellotti, L.; Borsari, M.; Bellei, M.; Bonifacio, A.; Bortolotti, C.A.; Di Rocco, G.; Ranieri, A.; Sola, M.; Battistuzzi, G. Ureainduced denaturation of immobilized yeast iso-1 cytochrome $c$ : Role of Met80 and Tyr67 in the thermodynamics of unfolding and promotion of pseudo-peroxidase and nitrite reductase activities. Electrochim. Acta 2020, 363, 137237. [CrossRef]

45. Bertini, I.; Cavallaro, G.; Rosato, A. Cytochrome $c$ : Occurrence and Functions. Chem. Rev. 2006, 106, 90-115. [CrossRef]

46. Moore, G.; Pettigrew, G.W.; Moore, G.R.; Pettigrew, G.W. Cytochromes c. Evolutionary, Structural, and Physicochemical Aspects; Springer: Berlin, Germany, 1990; ISBN 978-3-642-74536-2.

47. Scott, R.A.; Mauk, A.G. (Eds.) Cytochrome c-A Multidisciplinary Approach; University Science Books: Sausalito, CA, USA, 1996; ISBN 0-935702-33-4.

48. Alvarez-Paggi, D.; Hannibal, L.; Castro, M.A.; Oviedo-Rouco, S.; Demicheli, V.; Tórtora, V.; Tomasina, F.; Radi, R.; Murgida, D.H. Multifunctional Cytochrome $c$ : Learning New Tricks from an Old Dog. Chem. Rev. 2017, 117, 13382-13460. [CrossRef] [PubMed]

49. Yeh, S.-R.; Han, S.; Rousseau, D.L. Cytochrome $c$ folding and unfolding: A biphasic mechanism. Acc. Chem. Res. 1998, 31, 727-736. [CrossRef]

50. Pletneva, E.V.; Gray, H.B.; Winkler, J.R. Many faces of the unfolded state: Conformational heterogeneity in denatured yeast cytochrome c. J. Mol. Biol. 2005, 345, 855-867. [CrossRef] [PubMed]

51. Pletneva, E.V.; Gray, H.B.; Winkler, J.R. Nature of the cytochrome c molten globule. J. Am. Chem. Soc. 2005, 127, 15370-15371. [CrossRef]

52. Maity, H.; Maity, M.; Krishna, M.M.G.; Mayne, L.; Englander, S.W. Protein folding: The stepwise assembly of foldon units. Proc. Natl. Acad. Sci. USA 2005, 102, 4741-4746. [CrossRef] [PubMed]

53. Liu, J.; Chakraborty, S.; Hosseinzadeh, P.; Yu, Y.; Tian, S.; Petrik, I.; Bhagi, A.; Lu, Y. Metalloproteins Containing Cytochrome, Iron-Sulfur, or Copper Redox Centers. Chem. Rev. 2014, 114, 4366-4469. [CrossRef] [PubMed]

54. Battistuzzi, G.; Borsari, M.; Cowan, J.A.; Ranieri, A.; Sola, M. Control of Cytochrome $c$ Redox Potential: Axial Ligation and Protein Environment Effects. J. Am. Chem. Soc. 2002, 124, 5315-5324. [CrossRef]

55. Hannibal, L.; Tomasina, F.; Capdevila, D.A.; Demicheli, V.; Tórtora, V.; Alvarez-Paggi, D.; Jemmerson, R.; Murgida, D.H.; Radi, R.; Marmisollé, W.A.; et al. Alternative Conformations of Cytochrome c: Structure, Function, and Detection. Biochemistry 2016, 55, 407-428. [CrossRef]

56. Cherney, M.M.; Bowler, B.E. Protein dynamics and function: Making new strides with an old warhorse, the alkaline conformational transition of cytochrome c. Coord. Chem. Rev. 2011, 255, 664-677. [CrossRef]

57. Schweitzer-Stenner, R. Cytochrome $c$ : A Multifunctional Protein Combining Conformational Rigidity with Flexibility. New J. Sci. 2014, 2014, 1-28. [CrossRef]

58. Hüttemann, M.; Pecina, P.; Rainbolt, M.; Sanderson, T.H.; Kagan, V.E.; Samavati, L.; Doan, J.W.; Lee, I. The multiple functions of cytochrome $c$ and their regulation in life and death decisions of the mammalian cell: From respiration to apoptosis. Mitochondrion 2011, 11, 369-381. [CrossRef] [PubMed]

59. Baddam, S.; Bowler, B.E. Conformationally gated electron transfer in iso-1-cytochrome c: Engineering the rate of a conformational switch. J. Am. Chem. Soc. 2005, 127, 9702-9703. [CrossRef] [PubMed]

60. Battistuzzi, G.; Borsari, M.; Sola, M. Redox properties of cytochrome c. Antioxid. Redox Signal. 2001, 3, 279-291. [CrossRef]

61. Battistuzzi, G.; Borsari, M.; Sola, M. Medium and Temperature Effects on the Redox Chemistry of Cytochromec. Eur. J. Inorg. Chem. 2001, 2001, 2989-3004. [CrossRef]

62. Paradisi, A.; Bellei, M.; Paltrinieri, L.; Bortolotti, C.A.; Di Rocco, G.; Ranieri, A.; Borsari, M.; Sola, M.; Battistuzzi, G. Binding of S. cerevisiae iso-1 cytochrome $c$ and its surface lysine-to-alanine variants to cardiolipin: Charge effects and the role of the lipid to protein ratio. JBIC J. Biol. Inorg. Chem. 2020, 25, 467-487. [CrossRef]

63. Belikova, N.A.; Vladimirov, Y.A.; Osipov, A.N.; Kapralov, A.A.; Tyurin, V.A.; Potapovich, M.V.; Basova, L.V.; Peterson, J.; Kurnikov, I.V.; Kagan, V.E. Peroxidase Activity and Structural Transitions of Cytochrome $c$ Bound to Cardiolipin-Containing Membranes. Biochemistry 2006, 45, 4998-5009. [CrossRef]

64. Englander, S.W.; Sosnick, T.R.; Mayne, L.C.; Shtilerman, M.; Qi, P.X.; Bai, Y. Fast and Slow Folding in Cytochrome c. Acc. Chem. Res. 1998, 31, 737-744. [CrossRef]

65. Hoang, L.; Bédard, S.; Krishna, M.M.G.; Lin, Y.; Englander, S.W. Cytochrome $c$ folding pathway: Kinetic native-state hydrogen exchange. Proc. Natl. Acad. Sci. USA 2002, 99, 12173-12178. [CrossRef]

66. Fedurco, M.; Augustynski, J.; Indiani, C.; Smulevich, G.; Antalík, M.; Bánó, M.; Sedlák, E.; Glascock, M.C.; Dawson, J.H. The heme iron coordination of unfolded ferric and ferrous cytochrome $c$ in neutral and acidic urea solutions. Spectroscopic and electrochemical studies. Biochim. Biophys. Acta Proteins Proteom. 2004, 1703, 31-41. [CrossRef]

67. Fedurco, M.; Augustynski, J.; Indiani, C.; Smulevich, G.; Antalík, M.; Bánó, M.; Sedlák, E.; Glascock, M.C.; Dawson, J.H. Electrochemistry of unfolded cytochrome $c$ in neutral and acidic urea solutions. J. Am. Chem. Soc. 2005, 127, 7638-7646. [CrossRef]

68. Schweitzer-Stenner, R. Relating the multi-functionality of cytochrome $c$ to membrane binding and structural conversion. Biophys. Rev. 2018, 10, 1151-1185. [CrossRef] [PubMed] 
69. O'Reilly, N.J.; Magner, E.; Ivanova, E.V.; Magner, E.; O’Reilly, N.J.; Magner, E.; Konash, A.; Magner, E.; O’Reilly, N.J.; Magner, E. Electrochemistry of Cytochrome $c$ in Aqueous and Mixed Solvent Solutions: Thermodynamics, Kinetics, and the Effect of Solvent Dielectric Constant. Langmuir 2005, 21, 1009-1014. [CrossRef] [PubMed]

70. Crilly, S.; Magner, E. Reversible increase in the redox potential of cytochrome $c$ in methanol. Chem. Commun. 2009, 535-537. [CrossRef]

71. Battistuzzi, G.; Borsari, M.; Loschi, L.; Martinelli, A.; Sola, M. Thermodynamics of the alkaline transition of cytochrome $c$. Biochemistry 1999, 38, 7900-7907. [CrossRef]

72. Battistuzzi, G.; Borsari, M.; De Rienzo, F.; Di Rocco, G.; Ranieri, A.; Sola, M. Free Energy of Transition for the Individual Alkaline Conformers of Yeast Iso-1-cytochrome c. Biochemistry 2007, 46, 1694-1702. [CrossRef]

73. Battistuzzi, G.; Borsari, M.; Dallari, D.; Lancellotti, I.; Sola, M. Anion Binding to Mitochondrial Cytochromes $c$ Studied through Electrochemistry. Effects of the neutralization of surface charges on the redox potential. Eur. J. Biochem. 1996, 241, 208-214. [CrossRef] [PubMed]

74. Battistuzzi, G.; Borsari, M.; Sola, M. Anion binding to cytochrome c2: Implications on protein-ion interactions in class I cytochromes c. Arch. Biochem. Biophys. 1997, 339, 283-290. [CrossRef]

75. Díaz-Quintana, A.; Pérez-Mejías, G.; Guerra-Castellano, A.; De la Rosa, M.A.; Díaz-Moreno, I. Wheel and Deal in the Mitochondrial Inner Membranes: The Tale of Cytochrome $c$ and Cardiolipin. Oxid. Med. Cell. Longev. 2020, 2020, 6813405. [CrossRef] [PubMed]

76. Oellerich, S.; Wackerbarth, H.; Hildebrandt, P. Spectroscopic Characterization of Nonnative Conformational States of Cytochrome c. J. Phys. Chem. B 2002, 106, 6566-6580. [CrossRef]

77. Muenzner, J.; Pletneva, E.V. Structural transformations of cytochrome $c$ upon interaction with cardiolipin. Chem. Phys. Lipids 2014, 179, 57-63. [CrossRef]

78. Capdevila, D.A.; Marmisollé, W.A.; Tomasina, F.; Demicheli, V.; Portela, M.; Radi, R.; Murgida, D.H. Specific methionine oxidation of cytochrome $c$ in complexes with zwitterionic lipids by hydrogen peroxide: Potential implications for apoptosis. Chem. Sci. 2015, 6, 705-713. [CrossRef]

79. Capdevila, D.A.; Oviedo Rouco, S.; Tomasina, F.; Tortora, V.; Demicheli, V.; Radi, R.; Murgida, D.H. Active Site Structure and Peroxidase Activity of Oxidatively Modified Cytochrome $c$ Species in Complexes with Cardiolipin. Biochemistry 2015, 54, 7491-7504. [CrossRef] [PubMed]

80. Battistuzzi, G.; Borsari, M.; Rossi, G.; Sola, M. Effects of solvent on the redox properties of cytochrome $c$ : Cyclic voltammetry and 1 H NMR experiments in mixed water-dimethylsulfoxide solutions. Inorg. Chim. Acta 1998, 272, 168-175. [CrossRef]

81. Grealis, C.; Magner, E. The oxidation of cytochrome $c$ in nonaqueous solvents. Chem. Commun. 2002, 2, 816-817. [CrossRef] [PubMed]

82. Di Rocco, G.; Bighi, B.; Borsari, M.; Bortolotti, C.A.; Ranieri, A.; Sola, M.; Battistuzzi, G. Electron Transfer and Electrocatalytic Properties of the Immobilized Met80Ala Cytochrome $c$ Variant in Dimethylsulfoxide. ChemElectroChem 2021, 8, $2115-2123$. [CrossRef]

83. Yin, V.; Shaw, G.S.; Konermann, L.; Mian, S.H.; Konermann, L.; Shaw, G.S.; Konermann, L. Cytochrome $c$ as a Peroxidase: Activation of the Precatalytic Native State by $\mathrm{H}_{2} \mathrm{O}_{2}$-Induced Covalent Modifications. J. Am. Chem. Soc. 2017, 139, 15701-15709. [CrossRef]

84. Yin, V.; Mian, S.H.; Konermann, L. Lysine carbonylation is a previously unrecognized contributor to peroxidase activation of cytochrome $c$ by chloramine-T. Chem. Sci. 2019, 10, 2349-2359. [CrossRef]

85. Yin, V.; Holzscherer, D.; Konermann, L. Delineating heme-mediated versus direct protein oxidation in peroxidase-activated cytochrome $c$ by top-down mass spectrometry. Biochemistry 2020, 59, 4108-4117. [CrossRef]

86. Yin, V.; Konermann, L. Probing the Effects of Heterogeneous Oxidative Modifications on the Stability of Cytochrome $c$ in Solution and in the Gas Phase. J. Am. Soc. Mass Spectrom. 2021, 32, 73-83. [CrossRef]

87. Yeh, S.-R.; Rousseau, D.L. Folding intermediates in cytochrome c. Nat. Struct. Biol. 1998, 5, 222-228. [CrossRef]

88. Godbole, S.; Dong, A.; Garbin, K.; Bowler, B.E. A Lysine $73 \rightarrow$ Histidine Variant of Yeast Iso-1-cytochrome $c$ : Evidence for a Native-like Intermediate in the Unfolding Pathway and Implications for m Value Effects. Biochemistry 1997, 36, 119-126. [CrossRef]

89. Baddam, S.; Bowler, B.E. Mutation of asparagine 52 to glycine promotes the alkaline form of iso-1-cytochrome $c$ and causes loss of cooperativity in acid unfolding. Biochemistry 2006, 45, 4611-4619. [CrossRef] [PubMed]

90. Duncan, M.G.; Williams, M.D.; Bowler, B.E. Compressing the free energy range of substructure stabilities in iso-1-cytochrome $c$. Protein Sci. 2009, 18, 1155-1164. [CrossRef]

91. Elmer-Dixon, M.M.; Bowler, B.E. Electrostatic Constituents of the Interaction of Cardiolipin with Site A of Cytochrome $c$. Biochemistry 2018, 57, 5683-5695. [CrossRef]

92. Elmer-Dixon, M.M.; Xie, Z.; Alverson, J.B.; Priestley, N.D.; Bowler, B.E. Curvature-Dependent Binding of Cytochrome $c$ to Cardiolipin. J. Am. Chem. Soc. 2020, 142, 19532-19539. [CrossRef]

93. Kagan, V.E.; Bayir, H.A.; Belikova, N.A.; Kapralov, O.; Tyurina, Y.Y.; Tyurin, V.A.; Jiang, J.; Stoyanovsky, D.A.; Wipf, P.; Kochanek, P.M.; et al. Cytochrome c/cardiolipin relations in mitochondria: A kiss of death. Free Radic. Biol. Med. 2009, 46, 1439-1453. [CrossRef] [PubMed] 
94. Milazzo, L.; Tognaccini, L.; Howes, B.D.; Smulevich, G. Probing the non-native states of Cytochrome $c$ with resonance Raman spectroscopy: A tool for investigating the structure-function relationship. J. Raman Spectrosc. 2018, 49, 1041-1055. [CrossRef]

95. Milazzo, L.; Tognaccini, L.; Howes, B.D.; Sinibaldi, F.; Piro, M.C.; Fittipaldi, M.; Baratto, M.C.; Pogni, R.; Santucci, R.; Smulevich, G. Unravelling the Non-Native Low-Spin State of the Cytochrome c-Cardiolipin Complex: Evidence of the Formation of a His-Ligated Species Only. Biochemistry 2017, 56, 1887-1898. [CrossRef] [PubMed]

96. Sinibaldi, F.; Howes, B.D.; Droghetti, E.; Polticelli, F.; Piro, M.C.; Di Pierro, D.; Fiorucci, L.; Coletta, M.; Smulevich, G.; Santucci, R.; et al. Role of Lysines in Cytochrome c-Cardiolipin Interaction. Biochemistry 2013, 52, 4578-4588. [CrossRef]

97. Karsisiotis, A.I.; Deacon, O.M.; Wilson, M.T.; MacDonald, C.; Blumenschein, T.M.A.; Moore, G.R.; Worrall, J.A.R. Increased dynamics in the $40-57 \Omega$-loop of the G41S variant of human cytochrome $c$ promote its pro-apoptotic conformation. Sci. Rep. 2016, 6, 30447. [CrossRef] [PubMed]

98. Deacon, O.M.; Karsisiotis, A.I.; Moreno-Chicano, T.; Hough, M.A.; MacDonald, C.; Blumenschein, T.M.A.; Wilson, M.T.; Moore, G.R.; Worrall, J.A.R. Heightened Dynamics of the Oxidized Y48H Variant of Human Cytochrome $c$ Increases Its Peroxidatic Activity. Biochemistry 2017, 56, 6111-6124. [CrossRef] [PubMed]

99. Deacon, O.M.; Svistunenko, D.A.; Moore, G.R.; Wilson, M.T.; Worrall, J.A.R. Naturally Occurring Disease-Related Mutations in the 40-57 $\omega$-Loop of Human Cytochrome $c$ Control Triggering of the Alkaline Isomerization. Biochemistry 2018, 57, 4276-4288. [CrossRef] [PubMed]

100. Deacon, O.M.; White, R.W.; Moore, G.R.; Wilson, M.T.; Worrall, J.A.R. Comparison of the structural dynamic and mitochondrial electron-transfer properties of the proapoptotic human cytochrome $c$ variants, G41S, Y48H and A51V. J. Inorg. Biochem. 2020, 203, 110924. [CrossRef] [PubMed]

101. Tavagnacco, C.; Monari, S.; Ranieri, A.; Bortolotti, C.A.; Peressini, S.; Borsari, M. Immobilized unfolded cytochrome $c$ acts as a catalyst for dioxygen reduction. Chem. Commun. 2011, 47, 11122. [CrossRef]

102. Ranieri, A.; Battistuzzi, G.; Borsari, M.; Bortolotti, C.A.; Di Rocco, G.; Monari, S.; Sola, M. A bis-histidine-ligated unfolded cytochrome $c$ immobilized on anionic SAM shows pseudo-peroxidase activity. Electrochem. Commun. 2012, 14, 29-31. [CrossRef]

103. Ranieri, A.; Millo, D.; Di Rocco, G.; Battistuzzi, G.; Bortolotti, C.A.; Borsari, M.; Sola, M. Immobilized cytochrome $c$ bound to cardiolipin exhibits peculiar oxidation state-dependent axial heme ligation and catalytically reduces dioxygen. JBIC J. Biol. Inorg. Chem. 2015, 20, 531-540. [CrossRef]

104. Ranieri, A.; Di Rocco, G.; Millo, D.; Battistuzzi, G.; Bortolotti, C.A.; Lancellotti, L.; Borsari, M.; Sola, M. Thermodynamics and kinetics of reduction and species conversion at a hydrophobic surface for mitochondrial cytochromes $\mathrm{c}$ and their cardiolipin adducts. Electrochim. Acta 2015, 176, 1019-1028. [CrossRef]

105. Paradisi, A.; Lancellotti, L.; Borsari, M.; Bellei, M.; Bortolotti, C.A.; Di Rocco, G.; Ranieri, A.; Sola, M.; Battistuzzi, G. Met80 and Tyr67 affect the chemical unfolding of yeast cytochrome $c$ : Comparing the solution vs. immobilized state. RSC Chem. Biol. 2020, 1, 421-435. [CrossRef]

106. Santucci, R.; Sinibaldi, F.; Cozza, P.; Polticelli, F.; Fiorucci, L. Cytochrome $c$ : An extreme multifunctional protein with a key role in cell fate. Int. J. Biol. Macromol. 2019, 136, 1237-1246. [CrossRef] [PubMed]

107. Ascenzi, P.; Coletta, M.; Wilson, M.T.; Fiorucci, L.; Marino, M.; Polticelli, F.; Sinibaldi, F.; Santucci, R. Cardiolipin-cytochrome $c$ complex: Switching cytochrome $c$ from an electron-transfer shuttle to a myoglobin- and a peroxidase-like heme-protein. IUBMB Life 2015, 67, 98-109. [CrossRef]

108. Li, M.; Mandal, A.; Tyurin, V.A.; DeLucia, M.; Ahn, J.; Kagan, V.E.; van der Wel, P.C.A. Surface-Binding to Cardiolipin Nanodomains Triggers Cytochrome $c$ Pro-apoptotic Peroxidase Activity via Localized Dynamics. Structure 2019, 27, 806-815. [CrossRef]

109. Milorey, B.; Schweitzer-Stenner, R.; Kurbaj, R.; Malyshka, D. pH-Induced Switch between Different Modes of Cytochrome $c$ Binding to Cardiolipin-Containing Liposomes. ACS Omega 2019, 4, 1386-1400. [CrossRef]

110. Abe, M.; Niibayashi, R.; Koubori, S.; Moriyama, I.; Miyoshi, H. Molecular mechanisms for the induction of peroxidase activity of the cytochrome $c$-cardiolipin complex. Biochemistry 2011, 50, 8383-8391. [CrossRef] [PubMed]

111. Basova, L.V.; Kurnikov, I.V.; Wang, L.; Ritov, V.B.; Belikova, N.A.; Vlasova, I.I.; Pacheco, A.A.; Winnica, D.E.; Peterson, J.; Bayir, H.; et al. Cardiolipin switch in mitochondria: Shutting off the reduction of cytochrome $c$ and turning on the peroxidase activity. Biochemistry 2007, 46, 3423-3434. [CrossRef]

112. González-Arzola, K.; Díaz-Moreno, I.; Cano-González, A.; Díaz-Quintana, A.; Velázquez-Campoy, A.; Moreno-Beltrán, B.; López-Rivas, A.; De La Rosa, M.A.; Fersht, A.R. Structural basis for inhibition of the histone chaperone activity of SET/TAF-I $\beta$ by cytochrome c. Proc. Natl. Acad. Sci. USA 2015, 112, 9908-9913. [CrossRef] [PubMed]

113. Monari, S.; Millo, D.; Ranieri, A.; Di Rocco, G.; van der Zwan, G.; Gooijer, C.; Peressini, S.; Tavagnacco, C.; Hildebrandt, P.; Borsari, M. The impact of urea-induced unfolding on the redox process of immobilised cytochrome c. JBIC J. Biol. Inorg. Chem. 2010, 15, 1233-1242. [CrossRef] [PubMed]

114. Tomášková, N.; Varhač, R.; Lysáková, V.; Musatov, A.; Sedlák, E. Peroxidase activity of cytochrome $c$ in its compact state depends on dynamics of the heme region. Biochim. Biophys. Acta Proteins Proteom. 2018, 1866, 1073-1083. [CrossRef] [PubMed]

115. Monari, S.; Ranieri, A.; Di Rocco, G.; Van Der Zwan, G.; Peressini, S.; Tavagnacco, C.; Millo, D.; Borsari, M. Redox thermodynamics of cytochromes $c$ subjected to urea induced unfolding. J. Appl. Electrochem. 2009, 39, 2181-2190. [CrossRef]

116. Zámocký, M.; Hofbauer, S.; Schaffner, I.; Gasselhuber, B.; Nicolussi, A.; Soudi, M.; Pirker, K.F.; Furtmüller, P.G.; Obinger, C. Independent evolution of four heme peroxidase superfamilies. Arch. Biochem. Biophys. 2015, 574, 108-119. [CrossRef] 
117. Ying, T.; Wang, Z.-H.H.; Lin, Y.-W.W.; Xie, J.; Tan, X.; Huang, Z.-X.X. Tyrosine-67 in cytochrome $c$ is a possible apoptotic trigger controlled by hydrogen bonds via a conformational transition. Chem. Commun. 2009, 4512-4514. [CrossRef]

118. Liao, F.; Xu, J.K.; Luo, J.; Gao, S.Q.; Wang, X.J.; Lin, Y.W. Bioinspired design of an artificial peroxidase: Introducing key residues of native peroxidases into F43Y myoglobin with a Tyr-heme cross-link. Dalt. Trans. 2020, 49, 5029-5033. [CrossRef] [PubMed]

119. Lan, W.; Zhonghua, W.; Yang, Z.; Ying, T.; Zhang, X.; Tan, X.; Liu, M.; Cao, C.; Huang, Z.-X.X.; Wang, Z.Z.; et al. Structural basis for cytochrome $c \mathrm{Y} 67 \mathrm{H}$ mutant to function as a peroxidase. PLoS ONE 2014, 9, e107305. [CrossRef]

120. Tognaccini, L.; Ciaccio, C.; D’Oria, V.; Cervelli, M.; Howes, B.D.; Coletta, M.; Mariottini, P.; Smulevich, G.; Fiorucci, L. Structurefunction relationships in human cytochrome $c$ : The role of tyrosine 67. J. Inorg. Biochem. 2016, 155, 56-66. [CrossRef]

121. Cervelli, M.; Mariottini, P.; Smulevich, G.; Coletta, M.; Fiorucci, L. The Met80Ala and Tyr67His/Met80Ala mutants of human cytochrome $c$ shed light on the reciprocal role of Met80 and Tyr67 in regulating ligand access into the heme pocket. J. Inorg. Biochem. 2017, 169, 86-96. [CrossRef]

122. Lu, Y.; Casimiro, D.R.; Bren, K.L.; Richards, J.H.; Gray, H.B. Structurally engineered cytochromes with unusual ligand-binding properties: Expression of Saccharomyces cerevisiae Met-80 $\rightarrow$ Ala iso-1-cytochrome c. Proc. Natl. Acad. Sci. USA 1993, 90, 11456-11459. [CrossRef]

123. Bren, K.L.; Gray, H.B. Structurally engineered cytochromes with novel ligand-binding sites: Oxy and carbon monoxy derivatives of semisynthetic horse heart Ala80 cytochrome c. J. Am. Chem. Soc. 1993, 115, 10382-10383. [CrossRef]

124. Bren, K.L.; Gray, H.B.; Banci, L.; Bertini, I.; Turano, P. Paramagnetic 1H NMR spectroscopy of the cyanide derivative of Met80Ala-iso-1-cytochrome c. J. Am. Chem. Soc. 1995, 117, 8067-8073. [CrossRef]

125. Banci, L.; Bertini, I.; Bren, K.L.; Gray, H.B.; Turano, P.; Sompompisut, P.; Turano, P.; Banci, L.; Bertini, I.; Turano, P.; et al. $\mathrm{pH}$-dependent equilibria of yeast Met80Ala-iso-1-cytochrome $c$ probed by NMR spectroscopy: A comparison with the wild-type protein. J. Am. Chem. Soc. 1995, 2, 377-383. [CrossRef]

126. Banci, L.; Bertini, I.; Bren, K.L.; Gray, H.B.; Sompornpisut, P.; Turano, P.; Sompompisut, P.; Turano, P. Three-Dimensional Solution Structure of the Cyanide Adduct of a Variant of Saccharomyces cerevisiae Iso-1-cytochrome $c$ Containing the Met80Ala Mutation. Identification of Ligand-Residue Interactions in the Distal Heme Cavity. Biochemistry 1995, 34, 11385-11398. [CrossRef]

127. Battistuzzi, G.; Bortolotti, C.A.; Bellei, M.; Di Rocco, G.; Salewski, J.; Hildebrandt, P.; Sola, M. Role of Met80 and Tyr67 in the Low-pH Conformational Equilibria of Cytochrome c. Biochemistry 2012, 51, 5967-5978. [CrossRef]

128. Lin, R.; Bayachou, M.; Greaves, J.; Farmer, P.J. Nitrite Reduction by Myoglobin in Surfactant Films. J. Am. Chem. Soc. 1997, 119, 12689-12690. [CrossRef]

129. Immoos, C.E.; Chou, J.; Bayachou, M.; Blair, E.; Greaves, J.; Farmer, P.J. Electrocatalytic Reductions of Nitrite, Nitric Oxide, and Nitrous Oxide by Thermophilic Cytochrome P450 CYP119 in Film-Modified Electrodes and an Analytical Comparison of Its Catalytic Activities with Myoglobin. J. Am. Chem. Soc. 2004, 126, 4934-4942. [CrossRef] [PubMed]

130. Lojou, E.; Cutruzzolà, F.; Tegoni, M.; Bianco, P.; Cutruzzola, F.; Tegoni, M.; Bianco, P. Electrochemical study of the intermolecular electron transfer to Pseudomonas aeruginosa cytochrome cd1 nitrite reductase. Electrochim. Acta 2003, 48, 1055-1064. [CrossRef]

131. Berghuis, A.M.; Guillemette, J.G.; Smith, M.; Brayer, G.D. Mutation of tyrosine-67 to phenylalanine in cytochrome $c$ significantly alters the local heme environment. J. Mol. Biol. 1994, 235, 1326-1341. [CrossRef]

132. Berghuis, A.M.; Guillemette, J.G.; McLendon, G.; Sherman, F.; Smith, M.; Brayer, G.D. The Role of a Conserved Internal Water Molecule and Its Associated Hydrogen Bond Network in Cytochrfome c. J. Mol. Biol. 1994, 236, 786-799. [CrossRef] [PubMed]

133. Bortolotti, C.A.; Battistuzzi, G.; Borsari, M.; Facci, P.; Ranieri, A.; Sola, M. The Redox Chemistry of the Covalently Immobilized Native and Low-pH Forms of Yeast Iso-1-cytochrome c. J. Am. Chem. Soc. 2006, 128, 5444-5451. [CrossRef] [PubMed]

134. Chen, X.; Ferrigno, R.; Yang, J.; Whitesides, G.M. Redox properties of cytochrome $c$ adsorbed on self-assembled monolayers: A probe for protein conformation and orientation. Langmuir 2002, 18, 7009-7015. [CrossRef]

135. Levin, B.D.; Can, M.; Bowman, S.E.J.; Bren, K.L.; Elliott, S.J. Methionine Ligand Lability in Bacterial Monoheme Cytochromes c: An Electrochemical Study. J. Phys. Chem. B 2011, 115, 11718-11726. [CrossRef]

136. Monari, S.; Ranieri, A.; Bortolotti, C.A.; Peressini, S.; Tavagnacco, C.; Borsari, M.; Monari, S.; Ranieri, A.; Bortolotti, C.A.; Peressini, S.; et al. Unfolding of cytochrome $c$ immobilized on self-assembled monolayers. An electrochemical study. Electrochim. Acta 2011, 56, 6925-6931. [CrossRef]

137. Chen, X.; Peng, X.; Kong, J.; Deng, J. Facilitated electron transfer from an electrode to horseradish peroxidase in a biomembranelike surfactant film. J. Electroanal. Chem. 2000, 480, 26-33. [CrossRef]

138. Huerta-Miranda, G.A.; Arrocha-Arcos, A.A.; Miranda-Hernández, M. Gold nanoparticles/4-aminothiophenol interfaces for direct electron transfer of horseradish peroxidase: Enzymatic orientation and modulation of sensitivity towards hydrogen peroxide detection. Bioelectrochemistry 2018, 122, 77-83. [CrossRef]

139. Dunford, H.B. Oxidations of iron(II)/(III) by hydrogen peroxide: From aquo to enzyme. Coord. Chem. Rev. 2002, 233-234, 311-318. [CrossRef]

140. Baddam, S.; Bowler, B.E. Thermodynamics and kinetics of formation of the alkaline state of a Lys $79 \rightarrow$ Ala/Lys $73 \rightarrow$ His variant of iso-1-cytochrome $c$. Biochemistry 2005, 44, 14956-14968. [CrossRef] [PubMed]

141. Godbole, S.; Bowler, B.E. Effect of ph on formation of a nativelike intermediate on the unfolding pathway of a Lys $73 \rightarrow \mathrm{His}$ variant of yeast iso-1-cytochrome c. Biochemistry 1999, 38, 487-495. [CrossRef] [PubMed] 
142. Di Rocco, G.; Battistuzzi, G.; Bortolotti, C.A.; Borsari, M.; Ferrari, E.; Monari, S.; Sola, M. Cloning, expression, and physicochemical characterization of a new diheme cytochrome $c$ from Shewanella baltica OS155. JBIC J. Biol. Inorg. Chem. 2011, 16, 461-471. [CrossRef] [PubMed]

143. Liu, X.; Huang, Y.; Zhang, W.; Fan, G.; Fan, C.; Li, G.; Guo, K.; Hu, Y.; Zhang, Y.; Liu, B.; et al. Electrochemical investigation of redox thermodynamics of immobilized myoglobin: Ionic and ligation effects. Langmuir 2005, 21, 375-378. [CrossRef] [PubMed]

144. Bradley, J.M.; Silkstone, G.; Wilson, M.T.; Cheesman, M.R.; Butt, J.N. Probing a complex of cytochrome $c$ and cardiolipin by magnetic circular dichroism spectroscopy: Implications for the initial events in apoptosis. J. Am. Chem. Soc. 2011, 133, 19676-19679. [CrossRef] 